Review

\title{
Carrageenans as Broad-Spectrum Microbicides: Current Status and Challenges
}

\author{
Choongho Lee \\ College of Pharmacy, Dongguk University, Goyang 10326, Korea; lkj640@gmail.com; Tel.: +82-31-961-5223
}

Received: 12 July 2020; Accepted: 18 August 2020; Published: 21 August 2020

check for updates

\begin{abstract}
Different kinds of red algae are enriched with chemically diverse carbohydrates. In particular, a group of sulfated polysaccharides, which were isolated from the cell walls of red algae, gained a large amount of attention due to their broad-spectrum antimicrobial activities. Within that group, carrageenans (CGs) were expected to be the first clinically applicable microbicides that could prevent various viral infections due to their superior antiviral potency and desirable safety profiles in subclinical studies. However, their anticipated beneficial effects could not be validated in human studies. To assess the value of a second attempt at pharmacologically developing CGs as a new class of preventive microbicides, all preclinical and clinical development processes of CG-based microbicides need to be thoroughly re-evaluated. In this review, the in vitro toxicities; in vivo safety profiles; and in vitro, ex vivo, and in vivo antiviral activities of CGs are summarized according to the study volume of their target viruses, which include human immunodeficiency virus, herpesviruses, respiratory viruses, human papillomavirus, dengue virus, and other viruses along with a description of their antiviral modes of action and development of antiviral resistance. This evaluation of the strengths and weaknesses of CGs will help provide future research directions that may lead to the successful development of CG-based antimicrobial prophylactics.
\end{abstract}

Keywords: sulfated polysaccharides; carrageenans (CGs); broad-spectrum microbicides; in vitro and in vivo toxicity; in vitro; ex vivo; in vivo antiviral activity

\section{Introduction}

Microbicides are disinfectants designed to eliminate the infectivity of pathogenic microorganisms. In general, they render infectious microbes non-viable and prevent further transmission. When they are directed against viruses, they are often called virucides. The main antiviral mechanism of virucides involves chemical and physical destruction of the virus particle's structural components (i.e., envelope, enveloped glycoprotein, capsid, and nucleic acid). Unlike conventional antiviral drugs that specifically target essential viral and host functions necessary to complete the virus life cycle, virucides exert their antiviral actions primarily by targeting the viral entry step via direct disruption of the actual virus particles in a relatively less specific manner. For this reason, the systemic internal administration of microbicides is not recommended due to safety concerns. Instead, the external application of microbicides is the preferred administration route for the prevention of microbial transmission.

Carrageenans (CGs) are negatively charged polysaccharides isolated from the cell walls of red algae [1-3]. Along with cellulose sulfate and naphthalene sulfonate, CGs belong to a group of sulfated polysaccharides with a broad antiviral spectrum [4]. In particular, kappa $(\mathrm{K})$ and iota $(\iota)$ forms of CGs are linear polymers with a repeating disaccharide unit composed of sulfated galactose and anhydrogalactose, whereas the composition of lambda ( $\lambda$ ) form of CG is solely based on sulfated galactose without 3,6-anhydrogalactose (Figure 1). These two basic carbohydrate building blocks are connected via $\alpha-1,3$ and $\beta-1,4$ glycosidic linkages. Native carrageenan always present complex hybrid structures are generally a mixture of galactans composed of different carrabiose types, proportions, 
and structure of which vary with species algae. The number of sulfate groups dictates the physical property of these sulfated polyanionic substances. For example, $\mathrm{k}-\mathrm{CG}$, containing one sulfate, forms a rigid gel through a helix formation in ionic solutions, but iota $\mathrm{l}-\mathrm{CG}$, containing two sulfates, forms a flexible gel. In line with this trend, lambda $\lambda-C G$, containing three sulfates, does not possess a gel-forming property because it is devoid of 3,6-anhydrogalactose [5]. $\lambda$-CG is more frequently used as a thickener or a stabilizer instead. Due to their gelling, thickening, and stabilizing characteristics, CGs are widely used in the food industry. Recently, these sulfated polysaccharides showed promise as potential microbicides in the prevention of a variety of viral diseases [1-4,6]. CGs have demonstrated efficient neutralization of several clinically relevant viruses including human immunodeficiency virus (HIV), herpes simplex virus (HSV), influenza virus, human papillomaviruses (HPV), and dengue virus (DENV). In particular, the topical vaginal application of CGs protected mice against several sexually transmitted infections (STI) induced by both HIV and HSV [7-9]. Therefore, they were proposed as the most suitable candidates in a multipurpose STI prevention strategy that involves blocking the transmission of several STI-related viral infections at once. Also, the development of CG-based microbicides as pre-exposure prophylaxis in the form of topical gels was expected to provide a self-protective tool for women [10]. This may further contribute to the reduction of gender inequality arising from male-dominant decisions on sexual behavior. However, despite all of these promising results from subclinical in vitro and in vivo studies, clinical trials of several sulfated polysaccharides showed no beneficial effects as preventive measures against major viral infections [11,12]. In some cases, sulfated polysaccharides, paradoxically, enhanced viral infections, and caused a major drawback in their clinical development [13-15].

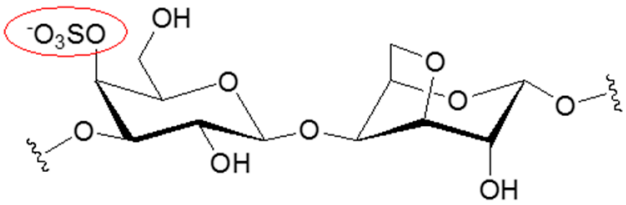

к-carrageenan

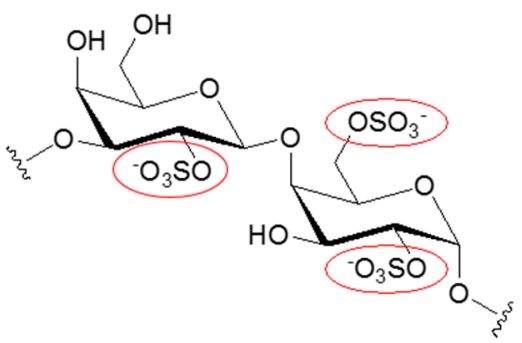

$\lambda$-carrageenan

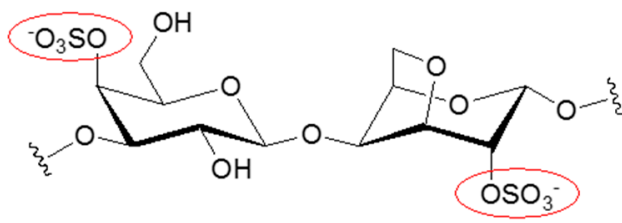

1-carrageenan

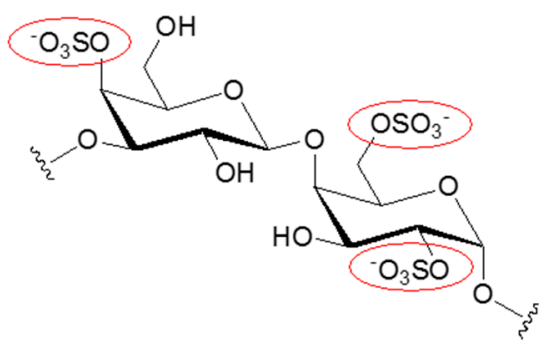

v-carrageenan

Figure 1. Chemical structures of different Carrageenans (CGs) including kappa ( $/$ ), iota ( $\iota)$, lambda $(\lambda)$, and nu $(v)$ forms. Only the repeating disaccharide unit of each CG is shown here. To emphasize the degree of sulfation, sulfated groups are highlighted with red circles.

To reassess the feasibility of the second round of CG pharmacological development to create a new class of preventive microbicides, all preclinical and clinical development processes of CG-based microbicides need to be thoroughly re-evaluated. Therefore, this review aims to provide a full picture of the current status and future challenges of developing CGs as broad-spectrum prophylactic microbicides. To this end, the in vitro toxicities and in vivo safety profiles of the most studied CGs are re-examined first. Then, their known common antiviral modes of action are explored at the molecular level. As HIV is the most studied antiviral target for CGs, their in vitro, ex vivo, and in vivo anti-HIV activities are re-examined in detail. In particular, the unexpected enhancement of HIV infectivity by CGs is also discussed. Concerning the anti-herpesvirus activities of CGs (herpesvirus is the second most 
studied antiviral target of CGs), the in vitro and in vivo effects of CGs on various types of herpesviruses, including HSV type 1, HSV type 2, and cytomegalovirus (CMV), are also described. In particular, the development of CG resistance by HSV is also discussed. Considering that the development of preventive measures against ongoing coronavirus-related pandemics is important, the effects of CGs on respiratory viruses such as rhinovirus, influenza virus, and coronavirus are also updated along with their effects on other viruses. Based on the strengths and weaknesses of CGs, a future research direction for a successful second round of CG development as a new class of preventive microbicides is proposed in the conclusion section.

\section{In Vitro Toxicity and In Vivo Safety}

The half-maximal cytotoxicity concentration $\left(\mathrm{CC}_{50}\right)$ is the gold standard when assessing the in vitro toxicity of potential antiviral candidates. Therefore, the $\mathrm{CC}_{50}$ values of $\mathrm{CGs}$ in different cell lines used in virus research were determined. The cell lines include MDCK cells, Vero cells, C6/36 HT mosquito cells, MDBK cells, BSR cells, MT-4 cells, PRK cells, HeLa cells, PLC/PRF/5, HepG2 cells, foreskin PH cells, mouse astrocytes, and BHK-21 cells. As shown in Table 1, their $\mathrm{CC}_{50}$ values range from 5 to $3000 \mu \mathrm{g} / \mathrm{mL}$ depending on the types of CGs and cell lines used [16-42]. Although more sulfated CGs such as $\lambda$-CG seems to be less toxic to cells than less sulfated CGs such as $\mathrm{k}$-and $\mathrm{l}-\mathrm{CG}$, it was difficult to draw any general relationship between the degree of sulfation and the cytotoxicity due to the presence of many outliers (Table 1). The unspecified CG used in the study by Huang et al. showed the lowest $\mathrm{CC}_{50}$, which was $5 \mu \mathrm{g} / \mathrm{mL}$ [29]. This might be due to their use of the unconventional cell viability quantitation method based on cellular oxygen consumption rates instead of a more traditional tetrazolium dye-based method [29]. The different origins of each cell line might also be responsible for the diverse effects of CGs on cell viability. Nevertheless, most in vitro CG studies demonstrated their superior cytotoxicity profiles; the highest $\mathrm{CC}_{50}$ values surpassed $1000 \mu \mathrm{g} / \mathrm{mL}$, which seems to be an unattainable concentration in in vivo application. However, the wide range of $\mathrm{CC}_{50}$ values of $\mathrm{CG}$ needs to be taken into account when CGs are applied to different tissues in vivo.

Table 1. In vitro CG toxicities. (CC 50 , half-maximal cytotoxicity concentration; MDCK cells, Madin-Darby canine kidney cells; MDBK cells, Madin-Darby bovine kidney cells; BHK-21 cells, baby hamster kidney 21-cells). When more than two CGs co-exist as a hybrid, they were listed together with a dash.

\begin{tabular}{cccc}
\hline CG Type & Cell Line & CC $_{50}(\mu \mathrm{g} / \mathrm{mL})$ & Ref \\
\hline K-CG & MDCK cells & $>250$ & {$[34]$} \\
\hline K-CG & Vero cells & $>1000$ & {$[43]$} \\
\hline K-CG & PRK cells & $>100$ & {$[18]$} \\
\hline K-CG & Vero cells & 2000 & {$[27]$} \\
\hline K-CG CO-1 & MDCK and A549 cells & 857 & {$[42]$} \\
\hline t-CG & Vero cells & 250 & {$[35]$} \\
\hline t-CG & Vero cells & $>1000$ & {$[21]$} \\
\hline t-CG & Vero cells & $>500$ & {$[19]$} \\
\hline L-CG & Vero and C6/36 HT mosquito cells & $>1000$ & {$[16]$} \\
\hline t-CG & Vero cells & $>400$ & {$[32]$} \\
\hline t-CG & Vero cells & $>5000$ & {$[43]$} \\
\hline$\lambda-C G$ & Vero cells & 400 & {$[17]$} \\
\hline
\end{tabular}


Table 1. Cont.

\begin{tabular}{|c|c|c|c|}
\hline CG Type & Cell Line & $\mathrm{CC}_{50}(\mu \mathrm{g} / \mathrm{mL})$ & Ref \\
\hline$\lambda-\mathrm{CG}$ & Vero cells & $>10$ & [31] \\
\hline$\lambda-\mathrm{CG}$ & Vero cells & $>1000$ & [23] \\
\hline$\lambda-\mathrm{CG}$ & MDBK cells & $>1000$ & [26] \\
\hline$\lambda-C G$ & Vero and C6/36 HT mosquito cells & $>1000$ & [37] \\
\hline$\lambda-C G$ & BSR cells & $>1000$ & [30] \\
\hline$\lambda-\mathrm{CG}$ & MT-4 cells & 300 & [41] \\
\hline$\lambda-\mathrm{CG}$ & Vero cells & $>5000$ & [43] \\
\hline$\lambda-\mathrm{CG}$ & PRK cells & $>100$ & [18] \\
\hline$\lambda-\mathrm{CG}$ & Vero cells & 3000 & [27] \\
\hline 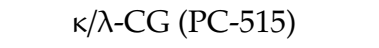 & Hela cells & $>16$ & [33] \\
\hline Oxidized k/l-CG & Vero cells & $>1000$ & [25] \\
\hline$\iota / \lambda-C G$ & HeLa cells & $>100$ & [20] \\
\hline $\mathrm{k} / \mathrm{l} / \lambda-\mathrm{CG}$ & PLC/PRF/5 cells & $>1000$ & [28] \\
\hline$\kappa / L / \lambda-C G$ & Vero, HepG2 and foreskin PH cells & $>1000$ & [36] \\
\hline$\kappa / L / \lambda-C G$ & Vero and C6/36 HT mosquito cells & $>1000$ & [38] \\
\hline$\kappa / l-C G, \lambda-C G$, and $v / v-C G$ & Vero and human foreskin fibroblast cells & $>1000$ & [22] \\
\hline $\mathrm{k} / \mathrm{l}-\mathrm{CG}, \lambda-\mathrm{CG}$, and $v / v-\mathrm{CG}$ & Mouse astrocytes and Vero cells & $>1000$ & [24] \\
\hline $\mathrm{k} / \mathrm{l} / \mathrm{v}-\mathrm{CG}$ & Vero, HepG2, and foreskin cells & $>1000$ & [39] \\
\hline k/l/v-CG C2 & Vero cells & $>1000$ & [40] \\
\hline Unspecified CG & BHK-21 fibroblast cells & $>5$ & [29] \\
\hline
\end{tabular}

Table 2 shows the in vivo safety profiles of three types of CG gels including $\mathrm{l}-\mathrm{CG}(\mathrm{PC}-213), \mathrm{k} / \lambda-\mathrm{CG}$ (PC-515), and $\kappa / \lambda-C G$ as well as a nonnucleoside reverse transcriptase inhibitor (MIV-150) and zinc acetate (ZA) (PC-1005) in eleven different clinical studies that recruited a variety of different cohorts based on HIV and sexual activity status. They were instructed to administer different types of CG gels with varying frequency and duration. Most of the clinical studies reported very high acceptability of CG gels because they did not irritate the female reproductive tract [44], caused no epithelial disruption [45], caused no vaginal floral change [46], and most importantly, did not increase proinflammatory cytokines in cervicovaginal lavages (CVLs) [47]. One study even reported increased sexual pleasure by using CG gel [48]. The addition of other pharmacological ingredients such as MIV-150 and ZA had no deleterious effects on the overall safety and acceptability of CG gels [49]. These data further indicate the superior safety profiles of CG gels when used alone or in conjunction with other preexisting anti-HIV therapeutics. Along with these desirable safety features, CGs also demonstrated effective anti-HIV efficacy. This was demonstrated by a lack of HIV RNA genital shedding [46], reduced HIV viral loads [50], and maintenance of anti-HIV activity in CVLs [49]. These desirable in vitro and in vivo safety properties demonstrated by CGs accelerated their clinical development. 
Table 2. CG in vivo safety in clinical studies. (STI, sexually transmitted infections; CVL, cervicovaginal lavage; HIV(-), HIV-negative; HIV(+), HIV-positive; MIV-150, nonnucleoside reverse transcriptase inhibitor; ZA, zinc acetate).

\begin{tabular}{|c|c|c|c|c|}
\hline CG Type & Human Subject & Duration and Frequency & Effects & Ref \\
\hline 2\% เ-CG (PC-213) & 25 women & Once a day for 1 week & $\begin{array}{l}\text { No irritation of the female } \\
\text { reproductive tract by } \\
\text { colposcopy }\end{array}$ & [44] \\
\hline $\begin{array}{l}3 \% \mathrm{k} / \lambda-\mathrm{CG} \\
(\mathrm{PC}-515)\end{array}$ & 165 women & 4 times per week for 1 year & $\begin{array}{l}\text { No abnormal clinical signs or } \\
\text { symptoms, no vaginal flora } \\
\text { change, and highly acceptable }\end{array}$ & [51] \\
\hline $\begin{array}{l}\text { 3\% K/入-CG } \\
(\mathrm{PC}-515)\end{array}$ & $55 \mathrm{HIV}(-)$ couples & $\begin{array}{l}\text { Before sexual intercourse } \\
\text { for } 6 \text { months }\end{array}$ & $\begin{array}{l}\text { Highly acceptable and } \\
\text { increased sexual pleasure }\end{array}$ & [48] \\
\hline $\begin{array}{l}3 \% \mathrm{k} / \lambda-\mathrm{CG} \\
(\mathrm{PC}-515)\end{array}$ & $\begin{array}{l}60 \mathrm{HIV}(+) \text { healthy } \\
\text { women and men }\end{array}$ & $\begin{array}{l}\text { Once a day or before } \\
\text { sexual intercourse for } \\
2 \text { weeks }\end{array}$ & Highly acceptable & [52] \\
\hline $\begin{array}{l}3 \% \mathrm{k} / \lambda-\mathrm{CG} \\
(\mathrm{PC}-515)\end{array}$ & $\begin{array}{l}60 \mathrm{HIV}(+) \text { healthy } \\
\text { women and men }\end{array}$ & $\begin{array}{l}\text { Once a day or before } \\
\text { sexual intercourse for } \\
2 \text { weeks }\end{array}$ & $\begin{array}{l}\text { No abnormal clinical signs or } \\
\text { symptoms, no vaginal flora } \\
\text { change, and no genital } \\
\text { shedding of HIV RNA }\end{array}$ & [46] \\
\hline $\begin{array}{l}3 \% \mathrm{k} / \lambda-\mathrm{CG} \\
(\mathrm{PC}-515)\end{array}$ & 55 HIV (-) women & $\begin{array}{l}\text { Before sexual intercourse } \\
\text { for } 1 \text { month }\end{array}$ & $\begin{array}{l}\text { Intact epithelium and no } \\
\text { increased proinflammatory } \\
\text { cytokines in CVL }\end{array}$ & [47] \\
\hline $\begin{array}{l}3 \% \mathrm{k} / \lambda-\mathrm{CG} \\
(\mathrm{PC}-515)\end{array}$ & $55 \mathrm{HIV}(-)$ couples & $\begin{array}{l}\text { 2-3 times per week before } \\
\text { sexual intercourse for } 6 \\
\text { months }\end{array}$ & $\begin{array}{l}\text { Generally acceptable, no } \\
\text { epithelial disruption, and no } \\
\text { abnormal genital flora }\end{array}$ & [45] \\
\hline $\begin{array}{l}3 \% \mathrm{k} / \lambda-\mathrm{CG} \\
(\mathrm{PC}-515)\end{array}$ & $\begin{array}{l}60 \mathrm{HIV}(+) \text { women } \\
\text { crossover }\end{array}$ & $\begin{array}{l}\text { Once daily for } 1 \text { week } \\
\text { followed by } 3 \text {-week } \\
\text { wash-out for } 1 \text { month }\end{array}$ & $\begin{array}{l}\text { Reduced HIV viral load in } \\
\text { CVL and well tolerated }\end{array}$ & [50] \\
\hline $\begin{array}{l}3 \% \mathrm{k} / \lambda-\mathrm{CG} \\
(\mathrm{PC}-515)\end{array}$ & $400 \mathrm{HIV}(-)$ women & $\begin{array}{l}3 \text { times a week before } \\
\text { sexual intercourse for } \\
6 \text { months }\end{array}$ & $\begin{array}{l}\text { No genital irritation or } \\
\text { epithelial disruption, no } \\
\text { difference in STI rate, and } \\
\text { generally acceptable }\end{array}$ & [53] \\
\hline $\begin{array}{l}3 \% \mathrm{k} / \lambda-\mathrm{CG} \\
(\mathrm{PC}-515)\end{array}$ & $\begin{array}{l}60 \mathrm{HIV}(+) \text { women } \\
\text { crossover }\end{array}$ & $\begin{array}{l}\text { Once-daily for } 1 \text { week for } \\
3 \text { months with cross-over }\end{array}$ & Highly acceptable & [54] \\
\hline $\begin{array}{l}3 \% \kappa / \lambda-C G+ \\
\text { MIV-150+ZA } \\
(\text { PC-1005) }\end{array}$ & $25 \mathrm{HIV}(-)$ women & Once-daily for 2 weeks & $\begin{array}{l}\text { Well tolerated and } \\
\text { maintenance of anti-HIV and } \\
\text { anti-HPV activity in CVL }\end{array}$ & [49] \\
\hline
\end{tabular}

\section{Mechanisms of Antiviral Action}

Before describing the antiviral effects of CGs on several clinically relevant viruses in detail, their common antiviral mode of action needs to be explained at the molecular level for a better understanding of their common pharmacological actions. In general, the electrostatic interactions between the anionic groups in the polysaccharide (mainly sulfates) and the basic amino acids of the virus glycoprotein is an essential requirement for the initial adsorption of a virus particle to the cell surface [2]. Particularly, the non-specific interaction of a virus glycoprotein with heparan sulfate on the cell surface serves as a necessary first step in the engagement of host receptors by a virus for successful viral entry. As a structural mimic to heparan sulfate, CGs form a complex with viral glycoproteins that prevents them from binding directly to the extracellular heparan sulfate. This blocks viral attachment and subsequent viral entry into a host cell.

In the case of HIV, CGs shield the positively charged sites of the HIV envelope glycoprotein (gp120) via electrostatic interactions [4]. Since this HIV-heparan sulfate interaction is necessary for initial HIV attachment to the cell surface before binding to the CD4 molecule of T cells, the interaction of CGs with gp120 interferes with the CD4-binding function of gp120, thereby blocking HIV entry [3]. In addition to this virus-targeting antiviral mechanism, CGs also exert antiviral actions via the inhibition of intercellular viral transmission [3]. For example, CGs inhibit the transfer of HIV from HIV-infected lymphocytes to uninfected epithelial cells [55]. The suppression of this intercellular HIV trafficking 
by CGs is thought to play a major role in the overall antiviral activity of CGs since the inhibitory concentrations required to target intercellular HIV trafficking by CGs were one thousand-fold lower than those required to target HIV entry [55].

Another host-targeting antiviral mechanism employed by CGs involves their direct binding to the CD4 protein of T cells [56]. Once bound to CGs, CD4 cannot interact with gp120, preventing infection of CD4-positive T cells by HIV [56]. In line with this, the association of CGs with CD4 inhibited anti-CD4 monoclonal antibodies from binding to CD4, itself [56]. However, the ability of gp120 to bind to monocytes was not affected by CGs, demonstrating their cell-type-specific antiviral effects [56].

Although the detailed molecular mechanism for these cell-type-specific antiviral activities of CGs is not clear, the difference in the proteoglycan compositions between T cells and monocytes may play a role in the differential antiviral actions of CGs. However, the antiviral activity of CGs tends to increase with either a higher molecular weight or a higher degree of sulfation $[3,57,58]$. Since antiviral activities of CGs mainly depend on neutralization of positively charged residues on either viral structural proteins or host receptors through electrostatic interaction, the increased negative charges on CGs by higher sulfation should contribute to the enhancement of the overall antiviral activities of CGs. In addition, the specific position of the sulfate ester group appears to be another critical determinant for the antiviral activity of sulfated polysaccharides [58]. Although the polyanionic nature of CGs is a critical factor for antiviral activity, the type of the anionic group also seems to be important. For example, carboxyl groups generally do not promote antiviral activity [58]. Thus, the antiviral activity is not merely a function of high charge density but has distinct structural specificities. Therefore, the nature of the negatively charged group and its position seem to influence their overall antiviral activities. The composition of the repeating carbohydrates of CGs affects their antiviral potency. Although one study demonstrated the higher antiviral potency of sulfated homopolysaccharides than sulfated heteropolysaccharides [57], this observation does not seem to be generalizable due to the presence of many other studies which suggests the opposite trend [58-60]. Of note, one group of researchers reported the selective inhibition of HIV reverse transcriptase and viral replication in vitro by a sea algal extract containing CGs; however, the exact intracellular anti-HIV mechanisms that are independent of virus entry disruption are not known [61]. Another group of researchers also reported a distinct antiviral mechanism of CGs that does not target virus entry $[62,63]$. They found that augmentation of natural killer cells and CG-induced infiltration of polymorphonuclear neutrophils inhibited the spread of murine cytomegalovirus from the peritoneal cavity to the plasma $[62,63]$. These two novel antiviral mechanisms exhibited by CGs deserve further attention to better understand CG virus-entry-independent antiviral properties. For those who wish to understand the in-depth antiviral mechanisms of action with a nice illustration, please refer to the following reference [6].

\section{Human Immunodeficiency Virus (HIV)}

\subsection{In Vitro Anti-HIV Activity}

HIV infection causes acquired immune deficiency syndrome (AIDS). Owing to the introduction of highly active antiretroviral therapy, AIDS became a clinically manageable disease. Nevertheless, continuous failures in developing HIV vaccines and a lack of effective preventive measures have been large hurdles in effectively controlling new HIV infections. Those who live in resource-poor and HIV-endemic regions have been most vulnerable to these recurring and uncontrolled HIV infections. Also, the unavailability of self-protective devices further aggravated the already uncontrollable state of new HIV infections [64]. Furthermore, the practice of unprotected receptive anal intercourse facilitated the spread of new HIV infections due to enriched HIV target cells in traumatized rectal mucosa [65]. Therefore, there is a desperate need for new HIV prevention strategies that mitigate HIV transmission. In this regard, CG-based topical anti-HIV gels were proposed as a promising on-demand, pre-exposure prophylactic option for the public. The antiviral activities of CGs in vitro, ex vivo, and in vivo along with the paradoxical increase of HIV infectivity by CGs are summarized below. 
One of the most frequently used methods to assess the in vitro potency of potential antiviral candidates is the determination of their half-inhibitory concentration $\left(\mathrm{IC}_{50}\right)$. For this purpose, the $\mathrm{IC}_{50}$ values of different CGs in several HIV-infected cell lines such as MT-4, CEM-SS, TMZ.bI, dendritic (DC), HeLa-CD4-CCR5, and P4-R5 MAGI cells were determined by using various anti-HIV assays (Table 3). These assays include plaque/cytopathic reduction assays, p24 ELISAs, luciferase assays, and microtiter syncytial assays. Their $\mathrm{IC}_{50}$ values ranged from 0.03 to $100 \mu \mathrm{g} / \mathrm{mL}$ depending on the cell type and experimental system. The $\mathrm{IC}_{50}$ values of most CGs were approximately 30 - to 160 -fold lower than their $\mathrm{CC}_{50}$ values, suggesting wide therapeutic windows, which is the most desirable feature for effective and safe pharmacological use (Table 1).

Table 3. CG in vitro anti-HIV activities. (AZT, azido-3'-deoxythymidine; ELISA, enzyme-linked immunosorbent assay).

\begin{tabular}{|c|c|c|c|c|}
\hline CG Type & Experimental System & Antiviral Assay & $\mathrm{IC}_{50}(\mu \mathrm{g} / \mathrm{mL})$ & Ref \\
\hline$\lambda-\mathrm{CG}$ & $\begin{array}{l}\text { MT-4 cells infected with } \\
\text { HIV-HTLVIIIB }\end{array}$ & $\begin{array}{l}\text { Expression of HIV-specific } \\
\text { antigens and plaque } \\
\text { reduction assays }\end{array}$ & $9500(\mathrm{IU} / \mathrm{mL})$ & [61] \\
\hline เ-CG & $\begin{array}{l}\text { MT-4 cells infected with } \\
\text { HIV }\end{array}$ & ELISA of p24 antigen & 100 & [56] \\
\hline ı-CG and k-CG & $\begin{array}{l}\text { MT- } 4 \text { cells and ME-180 } \\
\text { cells infected with HIV }\end{array}$ & ELISA of p24 antigen & 1.6 and 4 & [55] \\
\hline $\begin{array}{c}\text { Depolymerized } \\
\lambda \text {-CG }\end{array}$ & $\begin{array}{l}\text { MT-4 cells infected with } \\
\text { HIV-HTLVIIIB }\end{array}$ & $\begin{array}{l}\text { Expression of HIV-specific } \\
\text { antigens }\end{array}$ & $3.9\left(\mathrm{IC}_{100}\right)$ & [66] \\
\hline$\kappa-C G$ and $\lambda-C G$ & $\begin{array}{l}\text { MT-4 cells infected with } \\
\text { HIV-HTLVIIIB }\end{array}$ & $\begin{array}{l}\text { Expression of HIV-specific } \\
\text { antigens }\end{array}$ & 12 and 1.9 & [18] \\
\hline $\begin{array}{l}\text { K-CG and AZT } \\
\text { conjugates }\end{array}$ & $\begin{array}{l}\text { MT-4 cells infected with } \\
\text { HIV (BRU) }\end{array}$ & $\begin{array}{l}\text { Quantitation of } \\
\text { virus-induced } \\
\text { cytopathicity }\end{array}$ & 0.1 & [41] \\
\hline$\lambda / \kappa-C G+M I V-150$ & $\begin{array}{l}\text { CEM-SS cells infected with } \\
\text { HIVMN and } \\
\text { HIV-2CDC310342 }\end{array}$ & Microtiter syncytial assay & $0.1-13.8$ & [67] \\
\hline$\lambda / \kappa-C G(P C-515)$ & $\begin{array}{l}\text { TMZ.bI and DC cells } \\
\text { infected with HIV-Bal }\end{array}$ & $\begin{array}{l}\text { Quantitation of } \beta \text {-gal and } \\
\text { ELISA of p24 antigen }\end{array}$ & $0.03-4.17,1.61$ & [12] \\
\hline เ-CG & $\begin{array}{l}\text { HeLa-CD4-CCR5 cells } \\
\text { infected with HIVJR-FL }\end{array}$ & Luciferase assay & $1-10$ & [68] \\
\hline$\lambda-\mathrm{CG}$ & P4-R5 MAGI cells & ELISA of p24 antigen & 3.7 and 64 & [13] \\
\hline$\lambda-\mathrm{CG}$ & $\begin{array}{l}\text { MT-2 cells infected with } \\
\text { HIV BaL and IIIB }\end{array}$ & ELISA of p24 antigen & 0.58 and 0.68 & [14] \\
\hline
\end{tabular}

As mentioned previously, CGs such as t-CG inhibit HIV entry into lymphocytes and lymphocyte-to-epithelial transmission of HIV [55]. Interestingly, CG-induced suppression of lymphocyte-to-epithelial transmission of HIV occurred at concentrations one thousand times lower than the $\mathrm{IC}_{50}$ concentrations necessary for inhibition of HIV entry [55]. Since viral transfer is a critical step in successfully establishing HIV infection in the target cells, this mechanistically distinct antiviral mode of action might be useful for achieving maximal inhibition of HIV infection by CGs. On the other hand, the polymerization status of CGs seems to be an important determinant for their antiviral action since the depolymerized $\mathrm{k}$ - and $\mathrm{l}-\mathrm{CG}$ demonstrated much higher anti-HIV activities than native polymerized CGs [66]. In addition, direct covalent modification of CGs with other types of anti-HIV therapeutics synergized their antiviral activities. For example, when $\mathrm{k}-\mathrm{CG}$ was covalently conjugated with $3^{\prime}$-azido-3'-deoxythymidine (AZT, a reverse transcriptase inhibitor), its anti-HIV activities were enhanced [41]. The combined treatment of $\lambda$-CG with MIV-150 also reduced the original $\mathrm{IC}_{50}$ value of $\lambda$-CG by approximately 10 times [67]. These data indicate the utility of chemically modifying CGs or using them in combination with other antiviral drugs to improve their overall antiviral potency. 
As mentioned previously, higher CG antiviral activity is generated by increased sulfation. This was evident since $\lambda$-CG exhibited reduced $\mathrm{IC}_{50}$ values when compared to those of $\mathrm{k}$ - and $\mathrm{l}$-CGs (Table 3 ).

\subsection{Ex Vivo Anti-HIV Activity}

Five studies examined the anti-HIV activity of $\lambda / \kappa-C G$ in conjunction with MIV-150 and ZA ex vivo by using human cervical and macaque vaginal explants (Table 4). In general, human cervical and macaque vaginal tissues are excellent ex vivo models for testing the antiviral activities of candidate compounds against HIV infection because of their high in vivo similarity. These ex vivo studies reported that $\lambda / \kappa-C G$, alone or in conjunction with MIV-150 and ZA, successfully suppressed HIV infection. In particular, residual $\lambda / k-C G / M I V-150$, which was retrieved from the CVLs of human subjects after vaginal administration, maintained its inhibitory effects on HIV infections in human cervical explants [9]. In another study, vaginal application of MIV-150/ZA gel inhibited simian-human immunodeficiency virus reverse transcriptase (SHIV-RT) infection in macaque vaginal explants derived from monkeys when applied vaginally in a similar ex vivo setting [69]. Similarly, the addition of $\lambda / \kappa-C G$ in combination with MIV-150/ZA showed much greater anti-SHIV-RT activity than tenofovir gel in macaque vaginal explants [7]. In addition, this triple combination ( $\lambda / \kappa-C G / M I V-150 / Z A)$ gel completely protected macaque vaginal explants against free and cell-associated SHIV-RT infection [70]. These data further validate the superior antiviral activities of CGs in ex vivo conditions.

Table 4. CG ex vivo anti-HIV activities. (MIV-150, nonnucleoside reverse transcriptase inhibitor; ZA, zinc acetate; RT-SHIV, Simian immunodeficiency virus mac239 bearing HIV reverse transcriptase).

\begin{tabular}{|c|c|c|c|c|}
\hline CG Type & Experimental Systems & Antiviral Assay & Effects & Ref \\
\hline $\begin{array}{l}\lambda / \kappa-C G+M I V-150 \\
\quad+\mathrm{ZA}(\mathrm{PC}-1005)\end{array}$ & $\begin{array}{l}\text { Macaques vaginal explants } \\
\text { challenged with SHIV-RT }\end{array}$ & $\begin{array}{l}\text { Quantitation of viral DNA } \\
\text { and ELISA of SIVmac p27 }\end{array}$ & $\begin{array}{l}\text { Inhibition of } \\
\text { infection }\end{array}$ & [69] \\
\hline $\begin{array}{l}\lambda / \kappa-C G+M I V-150 \\
+ \text { ZA (PC-1005) }\end{array}$ & $\begin{array}{c}\text { Macaques vaginal explants } \\
\text { challenged with SHIV-RT } \\
\text { infected PBMCs }\end{array}$ & $\begin{array}{l}\text { Quantitation of viral DNA } \\
\text { and ELISA of SIVmac p27 }\end{array}$ & $\begin{array}{l}\text { Inhibition of } \\
\text { infection }\end{array}$ & [70] \\
\hline
\end{tabular}

\subsection{In Vivo Anti-HIV Activity}

Before testing them in a human clinical trial, the anti-HIV activities of CGs were first tested in mouse and macaque animal models (Table 5). In one mouse model, a $\lambda / \kappa-C G$ formulation blocked macrophage trafficking from the vagina to the lymph nodes [72]. Since the movement of macrophages from the vagina to lymph nodes is an essential step for HIV spread after initial infection, the specific blockage of this macrophage trafficking by CGs may delay the transmission of HIV to other parts of the body. When $\lambda / \kappa-C G$ was applied with either MIV-150, alone, or MIV-150/ZA as either vaginal or rectal gels, it also successfully diminished vaginal and rectal transmission of SHIV-RT infection in both vaginally and rectally challenged macaque models (Table 5) $[7,8,12,73,74]$. Of note, the addition of MIV-150 did not increase the antiviral activity of $\lambda / \kappa-C G$ in vivo. This is likely due to the limited activity of an MIV-150 single-dose and the dominant barrier effect of $\lambda / \kappa-C G$ [12]. The $\lambda / \kappa-C G / M I V-150 / Z A$ triple combination also demonstrated antiviral efficacy against rectal infection when administered close to the time of SHIV-RT exposure [75]. Vaginal SHIV-RT infection was also attenuated when macaques were challenged after the administration of $\lambda / k-C G$ plus ZA gel with modified buffers and cosolvent [8]. However, $\lambda / k-C G$, alone, showed limited activity against cell-free and mature DC-driven SHIV-RT infections [12]. Although low doses of $\lambda / k-C G$ enhanced SHIV-RT infection, the addition of 
MIV-150 with $\lambda / \kappa-C G$ treatment overcame this enhancement effect and blocked DC-transmitted HIV infection [12]. Despite these positive and preventive effects of CGs in different in vivo animal models, a randomized, double-blind, and placebo-controlled clinical study using $6202 \mathrm{HIV}$-negative women found similar HIV incidence rates and time to seroconversion in both placebo and $\lambda / \mathrm{k}$-CG-treated groups [11]. Although the safety profiles of $\lambda / k-C G$ gel were acceptable in this human study, the further development of CGs as a new class of anti-HIV microbicides was halted when $\lambda / \mathrm{k}-\mathrm{CG}$ demonstrated no beneficial effects on the prevention of vaginal transmission of HIV [11].

Table 5. CG in vivo anti-HIV activities. (MIV-150, nonnucleoside reverse transcriptase inhibitor; PBMC, peripheral blood mononuclear cells; ELISA, enzyme-linked immunosorbent assay; SHIV-RT, Simian immunodeficiency virus mac239 bearing HIV reverse transcriptase, TFV; tenofovir).

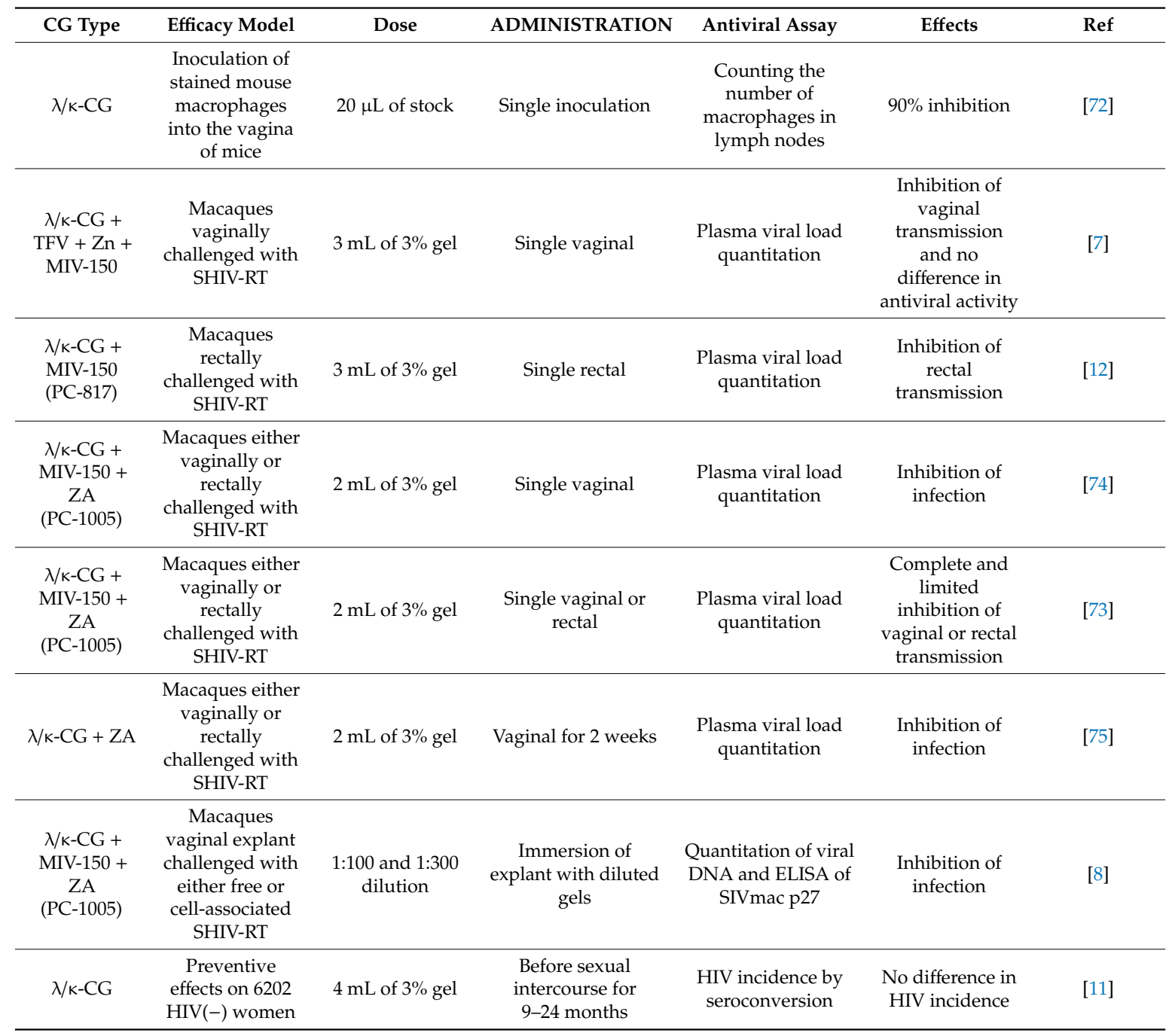

\subsection{Enhancement of HIV Infectivity}

Two studies noticed a seemingly paradoxical enhancement of HIV infection in the presence of polyanionic compounds [12,68]. Similarly, cellulose sulfate, which is a structural analog of CGs, also increased the risk of HIV infection [76]. In particular, cellulose sulfate showed a dose-dependent biphasic effect on HIV infection in vitro [15]. In this study, low concentrations of cellulose sulfate significantly and reproducibly increased HIV infection in in vitro experiments [15]. Similarly, in in vitro "washout" experiments, $\lambda$-CG also significantly enhanced HIV infection despite potent antiviral activity at higher concentrations [13]. This enhancement of HIV infection by a low dose of cellulose sulfate was further supported by one clinical study [77]. In this study, a higher number of newly acquired 
HIV infections was observed in the cellulose sulfate-treated patient group than the placebo group [77]. The exact molecular mechanism for concentration-dependent pro- and anti-viral effects of polyanionic compounds is still unclear. The interaction between a lower dose of polyanionic compounds with a virus particle might transform its overall structure into one that is more favorable for the engagement of the host receptor. This might lead to more efficient viral entry. This hypothesis needs to be tested in the future to resolve one of the most concerning side effects of CGs.

On the other hand, the formation of amyloid fibrils in semen was also shown to play a positive role in the promotion of HIV infection [78,79]. Since CGs improve the formation of amyloid fibrils, this might be a potential mechanism for the enhancement of HIV infection by CGs [14]. Of note, human defensins 5 and 6, which are produced by cervicovaginal epithelial cells, also significantly enhanced HIV infectivity [68]. They also antagonized the anti-HIV activity of CGs in vitro [68]. Interestingly, higher concentrations of polyanion microbicides, including CGs, suppressed the HIV-enhancing effects of human defensins 5 and 6 [68].

\section{Herpesviruses}

\subsection{In Vitro Anti-Herpesviruses Activity}

Herpesvirus infection is responsible for a wide variety of recurrent diseases such as cold sores, shingles, congenital defects, and several malignancies [80]. More than $90 \%$ of the adult population is estimated to be infected with one or more forms of herpesviruses [81]. They include herpes simplex virus type (HSV) 1, Epstein Barr virus (EBV), varicella-zoster virus (VZV), and human cytomegalovirus (HCMV). Fifteen different in vitro studies reported CG antiviral activities against different herpesviruses by using various cell lines such as Vero cells, PPK cells, Hela cells, human foreskin fibroblasts, mouse astrocytes, and MDBK cells [18,21-26,31,32,40,43,81-83] (Table 6). Quantitation of plaque-forming units and virus-induced cytopathic effects were used to determine their $\mathrm{IC}_{50}$ values. They vary from 0.01 to $34.3 \mu \mathrm{g} / \mathrm{mL}$ depending on the cell types, virus types, and experimental systems that were used. Their anti-herpesviruses $\mathrm{IC}_{50}$ value range seems to overlap with their anti-HIV IC 50 value range, which was from 0.03 to $100 \mu \mathrm{g} / \mathrm{mL}$ (Table 3). These data suggest that, similar to HIV, human herpesviruses (e.g., HSV-1, HSV-2, HCMV, and VZV) and animal herpesviruses (e.g., bovine herpesvirus type 1 [BoHV-1] and suid herpesvirus type 1 [SuHV-1]) are susceptible to CG inhibitory activities [18,21-26,31,32,40,81-83]. In particular, antiherpetic activity was directly correlated with the prevalence of alpha-D-galactose 2,6-disulfate residues in CGs [23]. Like HIV, virus adsorption also seems to be the main target for CG antiviral action since CGs did not affect internalization or early or late protein synthesis of herpesviruses [22]. Of note, anti-herpesvirus activity was increased by partial oxidation of $\mathrm{k}$-and l-CGs, which indicates the utility of structurally modifying CGs to improve their antiviral actions against herpesviruses [25]. In line with the key role of sulfated groups in the execution of antiviral activity in other viruses [43,58-60], the correlation of CG antiviral activity and the degree of their sulfation was also applicable to herpesviruses. For example, the antiviral IC50 values of fractions obtained from the same algal species against HSV-1 correlated well with their charge density induced by sulfation [23]. 
Table 6. CG in vitro anti-herpesvirus activities. (HSV, herpes simplex virus; CMV, cytomegalovirus; VZV, varicella-zoster virus; PFU, plaque-forming unit; CPE, cytopathic effect; PPK cells, primary porcine kidney cells; BoHV-1, bovine herpesvirus type 1; SuHV-1, suid herpesvirus type 1; MDBK cells, Madin-Darby bovine kidney cells).

\begin{tabular}{|c|c|c|c|c|c|}
\hline CG Type & Herpes Virus Type & Cell Line & Antiviral Assay & $\mathrm{IC}_{50}(\mu \mathrm{g} / \mathrm{mL})$ & Ref \\
\hline ı-CG & HSV-1 and 2 & Vero cells & PFU & 2 and 10 & [83] \\
\hline$\lambda / \kappa-C G$ & HSV-1 and 2 & PPK cells & CPE & $3.7,1.6,2,1.5$ & [18] \\
\hline$\lambda / \kappa-C G$ & CMV & Hela cells & $\mathrm{CPE}$ & $2.8 / 0.3$ & [18] \\
\hline$\lambda-C G$ & HSV-1 and 2 & Vero cells & $\mathrm{CPE}$ and $\mathrm{PFU}$ & $<100$ & [31] \\
\hline$\lambda-\mathrm{CG}$ & HSV-1 and 2 & Vero cells & $\mathrm{CPE}$ and $\mathrm{PFU}$ & 0.3 & [23] \\
\hline к-CG & HSV-2 & $\begin{array}{l}\text { Human foreskin } \\
\text { fibroblast cells }\end{array}$ & CPE & 0.01 & [81] \\
\hline $\begin{array}{l}\lambda \text {-CG type IV, } \\
\text { t-CG type V }\end{array}$ & HSV-2 & HeLa cells & $\mathrm{CPE}$ & 2.4 and 1.4 & [82] \\
\hline $\begin{array}{l}\lambda-\mathrm{CG} 1 \mathrm{T1}, \\
\text { к/l-CG 1C1, } \\
\mu / \nu-C G 1 C 3\end{array}$ & $\begin{array}{l}\text { HSV-1 strain F and } \\
\text { HSV-2 strain G }\end{array}$ & $\begin{array}{l}\text { Vero cells and } \\
\text { human diploid } \\
\text { foreskin fibroblast } \\
\text { cell line PH }\end{array}$ & PFU & $0.4-3.3$ & [22] \\
\hline $\begin{array}{l}\lambda-C G 1 T 1 \\
\kappa / \mathrm{L}-\mathrm{CG} 1 \mathrm{C} 1 \\
\mu / \mathrm{v}-\mathrm{CG} 1 \mathrm{C} 3\end{array}$ & $\begin{array}{l}\text { HSV-1 strain F and } \\
\text { HSV-2 strain G }\end{array}$ & $\begin{array}{l}\text { Mouse astrocytes } \\
\text { and Vero cells }\end{array}$ & PFU & $0.4-3.6$ & [24] \\
\hline ı-CG & HSV-1 and 2 & Vero cells & PFU & $0.65-9.33$ & [21] \\
\hline $\mathrm{k} / \mathrm{l} / \mathrm{v}-\mathrm{CG}, \mathrm{C} 2$ & $\begin{array}{l}\text { HSV-1 strain F and } \\
\text { HSV-2 strain G }\end{array}$ & Vero cells & PFU and survival & $0.5-5.6$ & [40] \\
\hline $\begin{array}{l}\text { Oxidized k- } \\
\text { and } \mathrm{l-CG}\end{array}$ & HSV-1 and 2 & Vero cells & PFU & $0.98-34.3$ & [25] \\
\hline$\lambda-\mathrm{CG}$ & $\begin{array}{l}\text { BoHV-1 and } \\
\text { SuHV-1 }\end{array}$ & MDBK cells & PFU & 0.52 and 10.42 & [26] \\
\hline ı-CG & HSV-1 & Vero cells & Neutral red dye & 6.31 & [32] \\
\hline$\kappa / \mathrm{l} / \lambda-C G$ & VZV & Vero cells & PFU & $0.5 / 0.8 / 1.8$ & [43] \\
\hline
\end{tabular}

\subsection{In Vivo Anti-Herpesviruses Activity}

Fifteen studies examined the antiviral effects of CGs on herpesviruses infection by using mouse and cat models $[7,8,40,62,63,82-89]$ (Table 7). CGs were used either alone or in combination with a variety of other antiviral drugs such as nonoxynol-9, ZA, griffithsin, and MIV-150. Among them, two studies confirmed CG antiviral activity against herpesviruses that did not target viral entry $[62,63]$. In these two studies, l-CG augmented NK activity of spleen cells and facilitated the infiltration of polymorphonuclear neutrophils into the peritoneal cavity and inhibited the spread of mouse cytomegalovirus (MCMV) from the peritoneal cavity to the plasma [62]. All of the other 13 studies verified the antiviral activities of CGs against HSV-2 infection via a common antiviral mechanism that involves disruption of viral entry. In particular, the CG-based formulations used by Maguire et al. were significantly more effective against herpesviruses infection than currently marketed spermicides containing the same amount of nonoxynol-9 [90].

The $\lambda$-CG 1T1 demonstrated irreversible virucidal action against herpesviruses [84]. By using the cat conjunctiva model, which is caused by feline herpesvirus-1 (FHV-1) infection, the antiviral activities of CGs were further confirmed [88]. In this study, $\lambda$ type IV CG shortened the duration of the FHV-1-positive period in FHV-1-infected cats [88]. CG, when combined with griffithsin, an algae-derived antiviral lectin protein, synergistically reduced HSV-2 vaginal infection in mice when administered before HSV-2 challenge [86]. Furthermore, this griffithsin/CG combination formulation, when administered in the form of a fast-dissolving insert, also protected mice against HSV-2 infection when applied vaginally [80]. These animal studies clearly demonstrated the superior antiviral activities of CGs in in vivo settings. 
Table 7. CG in vivo anti-herpesvirus activities. (PFU, plaque-forming unit; $\mathrm{LD}_{50}$, half-maximal lethal dose; MCMV, murine cytomegalovirus; FHV-1, feline herpesvirus-1; CPE, cytopathic effect; FDI, fast-dissolving insert; qPCR, quantitative polymerase chain reaction).

\begin{tabular}{|c|c|c|c|c|c|c|}
\hline CG Type & Efficacy Model & Dose & Antiviral Assay & Administration & Effects & Ref \\
\hline ı-CG type V & $\begin{array}{c}\text { ICR mice } \\
\text { infected with } \\
\text { MCMV }\end{array}$ & $0.5 \mathrm{mg}$ & PFU & Intraperitoneal & $\begin{array}{l}\text { Decreased } \\
\text { mortality and } \\
\text { titer and } \\
\text { increased } \\
\text { PFU/LD } 50\end{array}$ & [63] \\
\hline ı-CG type V & $\begin{array}{c}\text { ICR mice } \\
\text { infected with } \\
\text { MCMV }\end{array}$ & $0.5 \mathrm{mg}$ & PFU & Intraperitoneal & $\begin{array}{l}\text { Inhibition of } \\
\text { viral spread } \\
\text { from the } \\
\text { peritoneal cavity } \\
\text { to the plasma }\end{array}$ & [62] \\
\hline$\lambda / \kappa / \mathrm{l}-\mathrm{CG}$ & $\begin{array}{l}\text { BALB/c mice } \\
\text { infected with } \\
\text { HSV-2 }\end{array}$ & $0.05-1 \%$ & $\begin{array}{l}\text { PFU in vaginal } \\
\text { secretion }\end{array}$ & Vaginal & $\begin{array}{l}\text { Inhibition of } \\
\text { infection }\end{array}$ & [89] \\
\hline k-CG & $\begin{array}{c}\text { C57B1/6 mice } \\
\text { infected with } \\
\text { HSV-2 }\end{array}$ & $0.1-100 \mathrm{mg} / \mathrm{mL}$ & $\begin{array}{l}\text { Shedding of } \\
\text { virus, visible } \\
\text { lesions, and CPE }\end{array}$ & Vaginal & $\begin{array}{l}\text { Inhibition of } \\
\text { infection }\end{array}$ & [81] \\
\hline $\begin{array}{l}\text { CG-based } \\
\text { nonoxynol-9 }\end{array}$ & $\begin{array}{c}\text { BALB/c mice } \\
\text { infected with } \\
\text { HSV-2 }\end{array}$ & $20 \mathrm{ul}$ of $3 \%$ & $\begin{array}{l}\text { Symptom of } \\
\text { infection }\end{array}$ & Vaginal & $\begin{array}{l}\text { Inhibition of } \\
\text { infection }\end{array}$ & [90] \\
\hline $\begin{array}{l}\text { A-CG type IV } \\
\text { (1T1), l-CG } \\
\text { type V }\end{array}$ & $\begin{array}{l}\text { Swiss Webster } \\
\text { mice infected } \\
\text { with HSV-2 }\end{array}$ & $10 \mathrm{mg} / \mathrm{mL}$ & Sign of disease & Vaginal & $\begin{array}{l}\text { Inhibition of } \\
\text { infection }\end{array}$ & [82] \\
\hline$\lambda$-CG & $\begin{array}{c}\text { BALB/c mice } \\
\text { infected with } \\
\text { HSV-2 }\end{array}$ & 2 and $3 \%$ & Survival & Vaginal & $100 \%$ survival & [87] \\
\hline$\lambda$-CG $1 \mathrm{~T} 1$ & $\begin{array}{c}\text { BALB/c mice } \\
\text { infected with } \\
\text { HSV-2 }\end{array}$ & $10 \mathrm{mg} / \mathrm{mL}$ & $\begin{array}{l}\text { PFU and } \\
\text { survival }\end{array}$ & Vaginal & $\begin{array}{l}90 \% \text { survival } \\
\text { and no virus } \\
\text { shedding }\end{array}$ & [84] \\
\hline $\mathrm{kL} / \mathrm{v}-\mathrm{CG} \mathrm{C} 2$ & $\begin{array}{c}\text { BALB/c mice } \\
\text { infected with } \\
\text { HSV-2 }\end{array}$ & $8 \mathrm{mg} / \mathrm{mL}$ & $\begin{array}{l}\text { PFU and } \\
\text { survival }\end{array}$ & Vaginal & $70 \%$ survival & [40] \\
\hline$\lambda$-CG type IV & $\begin{array}{l}\text { FHV-1 induced } \\
\text { conjunctivitis in } \\
\text { cats }\end{array}$ & $250 \mu \mathrm{g} / \mathrm{mL}$ & PFU & Topical & $\begin{array}{l}\text { Reduction of } \\
\text { virus titers but } \\
\text { no alteration in } \\
\text { the clinical } \\
\text { course }\end{array}$ & [88] \\
\hline$\lambda / \kappa-C G+Z A$ & $\begin{array}{c}\text { BALB/c mice } \\
\text { infected with } \\
\text { HSV-2 }\end{array}$ & $20 \mu \mathrm{L}$ of $3 \%$ & Survival & $\begin{array}{l}\text { Vaginal and } \\
\text { rectal }\end{array}$ & $\begin{array}{l}\text { Inhibition of } \\
\text { infection }\end{array}$ & [85] \\
\hline$\lambda / \kappa-C G+Z A$ & $\begin{array}{c}\text { BALB/c mice } \\
\text { infected with } \\
\text { HSV-2 }\end{array}$ & $20 \mu \mathrm{L}$ of $3 \%$ & Survival & $\begin{array}{l}\text { Vaginal and } \\
\text { rectal }\end{array}$ & $\begin{array}{l}\text { Inhibition of } \\
\text { infection }\end{array}$ & [8] \\
\hline $\begin{array}{c}\mathrm{CG}+ \\
\text { griffithsin }\end{array}$ & $\begin{array}{c}\text { BALB/c mice } \\
\text { infected with } \\
\text { HSV-2 }\end{array}$ & $\begin{array}{c}50 \mu \mathrm{L} \text { of } \\
\text { griffithsin } \\
\text { solution } \\
(19.1 \mathrm{mg} / \mathrm{mL})\end{array}$ & Infection rate & Vaginal & $\begin{array}{l}\text { Inhibition of } \\
\text { infection }\end{array}$ & [86] \\
\hline $\begin{array}{c}\text { CG + } \\
\text { MIV-150 + } \\
\text { ZA }\end{array}$ & $\begin{array}{c}\text { BALB/c mice } \\
\text { infected with } \\
\text { HSV-2 }\end{array}$ & $10 \mu \mathrm{L}$ of stock & qPCR & Vaginal & $\begin{array}{l}\text { Inhibition of } \\
\text { infection }\end{array}$ & [7] \\
\hline $\begin{array}{c}\mathrm{CG}+ \\
\text { griffithsin }\end{array}$ & $\begin{array}{c}\text { BALB/c mice } \\
\text { infected with } \\
\text { HSV-2 }\end{array}$ & $\begin{array}{l}10 \mu \mathrm{L} \text { of } 0.1 \% \\
\text { stock }\end{array}$ & qPCR & Vaginal & $\begin{array}{l}\text { Inhibition of } \\
\text { infection }\end{array}$ & [80] \\
\hline
\end{tabular}




\subsection{CG-Resistant HSV Variants}

Due to the constantly mutating nature of RNA viruses, the development of drug resistance is inevitable during long-term usage of antiviral drugs. Therefore, the development of resistance to CGs by susceptible viruses needs to be monitored to assure consistent antiviral efficacy during their application. To gain insight into the development of CG resistance, HSV-1 was grown continuously in the presence of a low dose of CGs for a long period of time. As expected, HSV-1 variants arose after chronic selection with CGs [91]. These CG-resistant HSV-1 variants formed large plaques with an altered syncytial phenotype [91]. However, there was no correlation between the susceptibility of HSV-1 to CGs and its syncytial phenotype [91]. Instead, these CG-resistant HSV-1 variants showed a marked virulence when inoculated intranasally into mice and led to a generalized spread of the virus [92]. Also, mice infected intranasally with two syncytial variants of HSV-1 showed altered expression of cytokines [93]. The resistance-related characteristics of these HSV-1 syncytial variants need to be explored in more detail to understand the underlying mechanism that leads to CG resistance.

\section{Respiratory Viruses}

\subsection{In Vitro Anti-Respiratory Viruses Activity}

In general, respiratory viruses are defined as viruses that cause either upper or lower respiratory tract infections. Typically, they include influenza virus, parainfluenza virus, adenovirus, respiratory syncytial virus (RSV), human rhinovirus (HRV), and coronavirus. Eight studies examined CG in vitro antiviral activities against these respiratory viruses by using different susceptible cell lines (e.g., human nasal epithelial, HeLa, MDCK, and Vero cells) [34,42,94-99]. As shown in Table 8, most CGs suppressed respiratory virus propagation with $\mathrm{IC}_{50}$ values ranging from 0.04 to $276.5 \mu \mathrm{M}$. As with other antiviral studies, CGs blocked the adsorption of respiratory viruses. However, one study reported that the antiviral mechanism of action was independent of viral entry disruption. In this report, CGs inhibited influenza A virus mRNA and protein expression after viral internalization into cells [42]. In addition, l-CG-containing over the counter (OTC) products such as lozenges and Coldmaris were also highly active against respiratory viruses such as HRV 1a, HRV8, influenza virus A H1N1, coxsackievirus A10, and human coronavirus OC43 [94,97]. Considering the ongoing coronavirus pandemics, a nasal spray of CG-containing OTC products might be helpful for the prevention of coronavirus transmission. 
Table 8. CG in vitro anti-respiratory virus activities. (TCID 50 , median tissue culture infectious dose; MDCK cells, Madin-Darby canine kidney cells; PFU, plaque-forming unit; CPE, cytopathic effect; IF, immunofluorescence; HRV, human rhinovirus).

\begin{tabular}{|c|c|c|c|c|c|}
\hline CG Type & Virus Type & Cell Line & Anti-Viral Assay & $\mathrm{IC}_{50}(\mu \mathrm{g} / \mathrm{mL})$ & Ref \\
\hline ı-CG & $\begin{array}{l}\text { HRV } 1 \mathrm{~A}, 2,8,14, \\
16,83 \text {, and } 84\end{array}$ & $\begin{array}{l}\text { Human nasal } \\
\text { epithelial and } \\
\text { HeLa cells }\end{array}$ & $\mathrm{TCID}_{50}$ & $5-10$ & [95] \\
\hline ı-CG & $\begin{array}{c}\text { Influenza virus } \\
\text { strain H1N1 } \\
\text { (A/PR8/34) and the } \\
\text { formerly pandemic } \\
\text { H3N2 } \\
\text { (A/Aichi/2/68) }\end{array}$ & $\begin{array}{l}\text { MDCK cells and } \\
\text { human nasal } \\
\text { epithelial cells }\end{array}$ & PFU & $0.04-0.2$ & [96] \\
\hline k-CG & Influenza A virus & $\begin{array}{l}\text { MDCK and A549 } \\
\text { cells }\end{array}$ & $\begin{array}{l}\text { TCID }_{50} \text { assay and } \\
\text { RT-PCR }\end{array}$ & 32.1 & [42] \\
\hline $\begin{array}{l}l / k / v-C G \\
\text { hybrid }\end{array}$ & $\begin{array}{c}\text { Influenza A H1N1 } \\
\text { virus }\end{array}$ & MDCK cells & CPE inhibition & 276.5 & [99] \\
\hline $\begin{array}{l}\text { l-CG + } \\
\text { zanamivir }\end{array}$ & $\begin{array}{c}\text { Influenza A virus } \\
\text { H1N1(09)pdm, } \\
\text { H3N2, H5N1, and } \\
\text { H7N7 }\end{array}$ & MDCK cells & Immunostaining & $0.39-11.8$ & [98] \\
\hline k-CG & $\begin{array}{c}\text { Swine pandemic } \\
\text { influenza A virus } \\
\text { H1N1 }\end{array}$ & MDCK cells & $\begin{array}{c}\mathrm{TCID}_{50}, \mathrm{CPE} \\
\text { experiments, IF, } \\
\text { and Western blot }\end{array}$ & 89.57 & [34] \\
\hline ı-CG (lozenges) & $\begin{array}{c}\text { HRV 1a, HRV8, } \\
\text { influenza virus A } \\
\text { H1N1, } \\
\text { coxsackievirus A10, } \\
\text { and human } \\
\text { coronavirus OC43 }\end{array}$ & $\begin{array}{c}\text { HeLa, MDCK, and } \\
\text { Vero cells }\end{array}$ & $\begin{array}{l}\mathrm{TCID}_{50} \text { and PFU, } \\
\text { agglutination assay }\end{array}$ & $\begin{array}{l}234-4524 \\
\text { dilution }\end{array}$ & [97] \\
\hline $\begin{array}{l}\text { l-CG and } \\
\text { xylometazoline } \\
\text { hydrochloride } \\
\text { (Coldamaris) }\end{array}$ & $\begin{array}{c}\text { HRV 1a, HRV8, } \\
\text { and human } \\
\text { coronavirus OC43 }\end{array}$ & $\begin{array}{l}\text { HeLa, MDCK, and } \\
\text { Vero cells }\end{array}$ & $\begin{array}{l}\mathrm{TCID}_{50} \text { and PFU, } \\
\text { agglutination assay }\end{array}$ & $\begin{array}{c}16.5,1.66, \text { and } \\
0.024\end{array}$ & [94] \\
\hline
\end{tabular}

\subsection{In Vivo Anti-Respiratory Viruses Activity}

Five studies tested the in vivo antiviral potency of CGs against respiratory viruses alone or in conjunction with zanamivir, which is a neuraminidase inhibitor of the influenza virus, by using mouse models (Table 9) [96,100-103]. First, Fujisawa et al. found that type II CGs depleted macrophages and increased polymorphonuclear leukocytes, resulting in an enhanced influenza virus titer [100]. Based on this data, they suggested that type II CG-resistant polymorphonuclear leukocytes play a protective role during the early stages of influenza virus infection [100]. This virus-assisting effect of type II CGs seems to be independent of viral adsorption inhibition [102]. In contrast to this report, three in vivo mouse studies found decreased viral titers, increased host survival, inhibition of pulmonary edema, decreased weight loss, and reduced necropsy and inflammation when mice were pretreated with CGs, and then challenged with influenza A virus $[96,98,101]$. In particular, infecting mice with a lethal dose of influenza A virus followed by I-CG treatment protected mice to a similar degree as mice treated with oseltamivir, which is another neuraminidase inhibitor of influenza virus [96]. The intranasal application of zanamivir and $\mathrm{k} / \mathrm{L} C \mathrm{C}$ is also synergistically active against influenza $\mathrm{A}$ virus in the murine model [98]. One study evaluated the safety of t-CG via an intranasal route by using animal models [104]. This study revealed no penetration of $\mathrm{l}-\mathrm{CG}$ across nasal mucosa and no systemic delivery of $\mathrm{t}-\mathrm{CG}$ into the bloodstream [104]. Consistently, no relevant toxic or secondary pharmacological effects due to systemic exposure were observed in the rabbit or rat repeated dose toxicity studies [104]. In addition, no signs of immunogenicity or immunotoxicity and no stimulation of a panel of pro-inflammatory cytokines were observed by the treatment of $\mathrm{I-CG}$ in both in vivo and in vitro models [104]. 
Five clinical studies also supported the beneficial effects of CGs in alleviating clinical symptoms and reducing viral loads (Table 10) [61,105-109]. In particular, the administration of a l-CG nasal spray reduced symptoms of the common cold and viral loads in nasal lavages in patients with early symptoms of the common cold [105]. Although I-CG treatment failed to alleviate acute common cold symptoms in children, it did significantly reduce viral loads in nasal secretions [106]. Another study also reported that direct local administration of CGs via nasal sprays reduced the duration of cold symptoms and viral loads in nasal wash fluids [107].

Table 9. CG anti-respiratory virus activities in vivo animal studies. (MDCK cells, Madin-Darby canine kidney cells; PMN, polymorphonuclear leukocytes; BID, twice a day; RSV, respiratory syncytial virus).

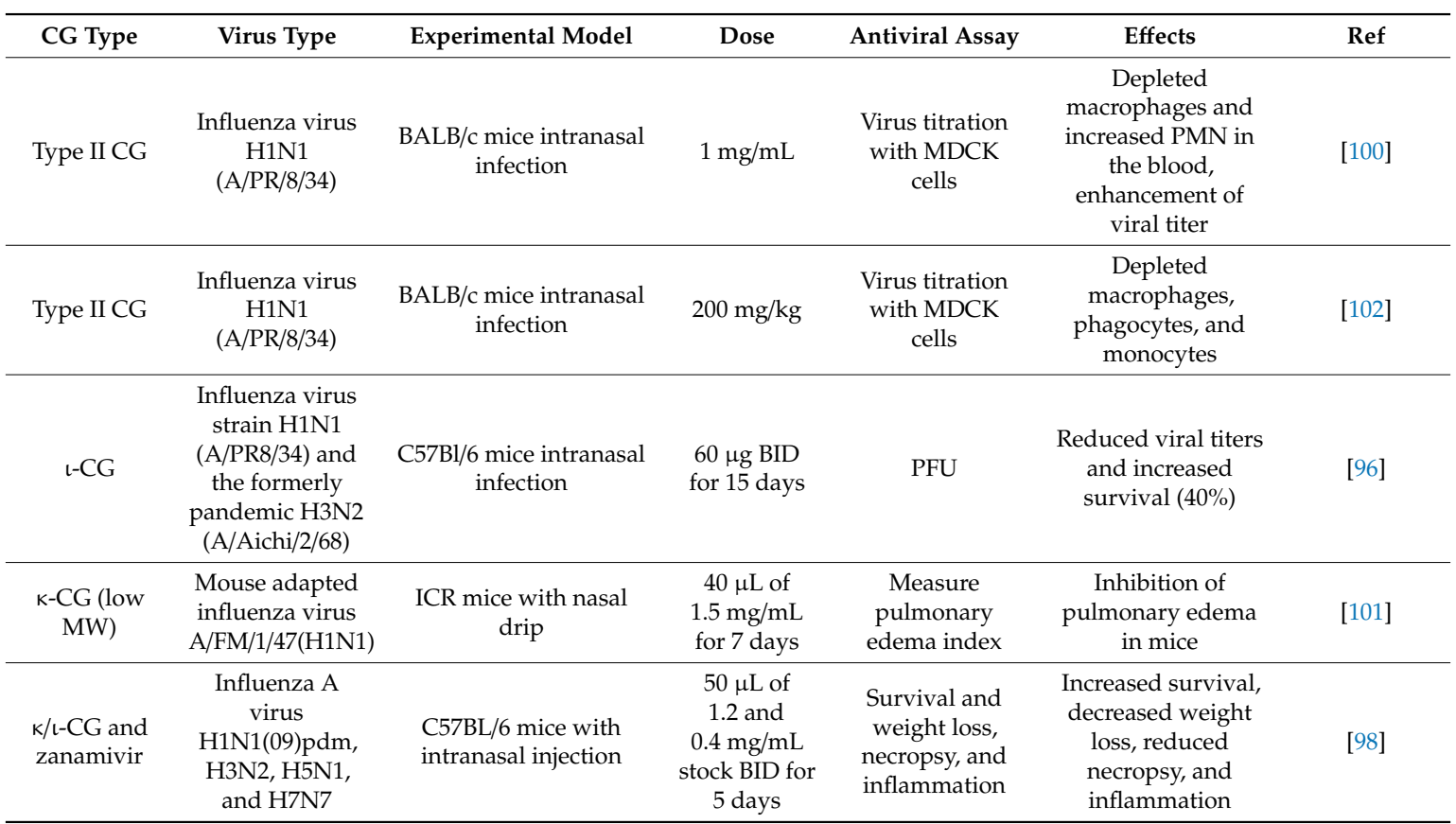

Table 10. CG anti-respiratory virus activities in clinical studies. (BID, twice a day; RSV, respiratory syncytial virus).

\begin{tabular}{|c|c|c|c|c|c|c|}
\hline CG Type & Virus Type & Experimental Model & Dose & Antiviral Assay & Effects & Ref \\
\hline $\begin{array}{c}\stackrel{\mathrm{I}-\mathrm{CG}}{\text { (Coldmaris) }} \\
\text { (1) }\end{array}$ & $\begin{array}{c}\text { Respiratory viruses } \\
\text { (influenza, parainfluenza, } \\
\text { coronavirus, rhinoviruses, } \\
\text { and human } \\
\text { metapneumovirus) }\end{array}$ & $\begin{array}{c}35 \text { human subjects, } \\
\text { nasal spray, symptom } \\
\text { scores }\end{array}$ & $0.12 \%$ & $\begin{array}{l}\text { Measure viral } \\
\text { loads in nasal } \\
\text { lavages }\end{array}$ & $\begin{array}{l}\text { Lowered symptom } \\
\text { scores and viral } \\
\text { loads, lowered } \\
\text { proinflammatory } \\
\text { cytokines }\end{array}$ & [105] \\
\hline $\begin{array}{c}\stackrel{\mathrm{I}-\mathrm{CG}}{\text { (Coldmaris) }} \\
\text { (a) }\end{array}$ & $\begin{array}{l}\text { Respiratory viruses } \\
\text { (influenza, parainfluenza, } \\
\text { coronavirus, RSV, } \\
\text { rhinoviruses, and human } \\
\text { metapneumovirus) }\end{array}$ & $\begin{array}{l}213 \text { young human } \\
\text { subjects, nasal spray, } \\
\text { symptom scores }\end{array}$ & $0.12 \%$ & $\begin{array}{l}\text { Measure viral } \\
\text { loads in nasal } \\
\text { lavages }\end{array}$ & $\begin{array}{l}\text { Lowered viral loads } \\
\text { but no effects on } \\
\text { symptom scores }\end{array}$ & [106] \\
\hline $\begin{array}{c}\text { I-CG } \\
\text { (Coldmaris) }\end{array}$ & $\begin{array}{c}\text { Respiratory viruses } \\
\text { (influenza, parainfluenza, } \\
\text { coronavirus, RSV, } \\
\text { rhinoviruses, and human } \\
\text { metapneumovirus) }\end{array}$ & $\begin{array}{l}211 \text { patients intranasal } \\
\text { spray }\end{array}$ & $0.12 \%$ & $\begin{array}{l}\text { Measure viral } \\
\text { loads in nasal } \\
\text { lavages }\end{array}$ & $\begin{array}{l}\text { Reduced duration of } \\
\text { disease, alleviation } \\
\text { of symptom, and } \\
\text { reduced viral titers }\end{array}$ & [107] \\
\hline เ-CG & $\begin{array}{l}\text { Rhinovirus, coronavirus, } \\
\text { and influenza A virus }\end{array}$ & $\begin{array}{l}200 \text { human subjects } \\
\text { with nasal spray }\end{array}$ & $\begin{array}{l}0.12 \% \text { QID } \\
\text { for } 4-10 \text { days }\end{array}$ & $\begin{array}{l}\text { Nasal lavage } \\
\text { sample }\end{array}$ & $\begin{array}{l}\text { No difference in } \\
\text { total symptom } \\
\text { scores and more } \\
\text { effective in } \\
\text { coronavirus }\end{array}$ & [109] \\
\hline
\end{tabular}


The low molecular weight version of $\mathrm{k}-\mathrm{CG}$ also significantly suppressed mouse-adapted influenza virus-induced pulmonary edema [101]. The administration of a CG nasal spray diminished virus-confirmed common cold duration in children as well as in adults. It also increased viral clearance and reduced symptom relapse [108]. ı-CG also significantly reduced rhinovirus/enterovirus-induced cold symptoms relative to a placebo during the first four days when symptoms were most severe [109]. These data further suggest that CGs have highly active antiviral potentials against a variety of respiratory viruses.

\section{Human Papillomavirus (HPV)}

\subsection{In Vitro Anti-HPV Activity}

High-risk type HPV infection is a major cause of cervical cancer development in women. Five studies examined the in vitro antiviral activities of CGs against different types of HPV including HPV6, 16, 18, 31, 34, 45, and 58 using HeLa, 293T, and NCI-60 cells [20,33,86,110,111] (Table 11). Interestingly, genital HPVs were approximately one thousand-fold more susceptible to CGs since their $\mathrm{IC}_{50}$ values against HPVs were all within nanomolar ranges. In addition to this superior antiviral potency, CGs blocked HPV infection through a second, post-attachment heparan sulfate-independent effect in addition to their heparan sulfate-mimicking antiviral mechanism [20]. Since alpha 6 integrin is a major host receptor necessary for HPV infection, CG-induced alpha 6 integrin internalization may also contribute to reduced availability of the host receptor. These three distinct antiviral mechanisms may play a role in facilitating nanomolar CG antiviral activities against HPV infection [86]. Since HPV capsids specifically bind to tumors in a heparan sulfate-dependent manner in vitro and in vivo, t-CG treatment blocked HPV binding and infection in all tumor lines [110]. In line with this, a CG-based vaginal lubricant maintained in vitro inhibitory activity against HPV infection according to CVLs collected after sexual intercourse [112].

Table 11. CG in vitro anti-HPV activities. (GFP, green fluorescence; RFP, red fluorescence; FACS, Fluorescence-activated cell sorting; PsVs, pseudoviruses).

\begin{tabular}{|c|c|c|c|c|c|}
\hline CG Type & Virus Type & Experimental System & Anti-Viral Assay & $\mathrm{IC}_{50}(\mathrm{ng} / \mathrm{mL})$ & Ref \\
\hline$\lambda / \mathrm{l}-\mathrm{CG}$ & HPV16 & $\begin{array}{l}\text { HeLa cells infected } \\
\text { with pseudovirus } \\
\text { with GFP }\end{array}$ & GFP assay & $5-44$ & [20] \\
\hline $\begin{array}{l}\kappa / \lambda-C G \\
(\mathrm{PC}-515)\end{array}$ & $\begin{array}{c}\text { HPV16, 18, and } \\
45 \text { PsVs }\end{array}$ & $\begin{array}{c}\text { HeLa cells infected } \\
\text { with pseudovirus with } \\
\text { luciferase }\end{array}$ & Luciferase assay & $1-20$ & [33] \\
\hline CG & $\begin{array}{c}\text { HPV16, } 18,31, \\
34,58, \text { and } 6 \\
\text { with luciferase } \\
\text { reporter }\end{array}$ & $\begin{array}{c}\text { 293T cell infected with } \\
\text { furin-cleaved HPV16 } \\
\text { pseudovirus }\end{array}$ & Luciferase assay & 250-1000 & [111] \\
\hline CG & HPV16 & $\begin{array}{c}\text { HeLa cells infected } \\
\text { with pseudovirus with } \\
\text { luciferase }\end{array}$ & Luciferase assay & 38.6 & [86] \\
\hline $1 \%$ เ-CG & $\begin{array}{l}\text { HPV } 16 \text { VLP } \\
\text { and PsV }\end{array}$ & $\begin{array}{l}\text { NCI-60 cells infected } \\
\text { with RFP-encoded } \\
\text { HPV pseudovirus }\end{array}$ & GFP assay by FACS & $\mathrm{N} / \mathrm{D}$ & [110] \\
\hline
\end{tabular}

\subsection{In Vivo Anti-HPV Activity}

The in vivo anti-HPV activities of CGs were tested using mouse and macaque models (Table 12). The I-CG treatment prevented HPV infection even in the presence of nonoxynol-9, which is a vaginal spermicide [113]. This HPV-suppressive property of t-CG was encouraging since nonoxynol-9 greatly increased HPV infection susceptibility in a previous study [90,113]. A CG-containing gel also caused significantly less HPV infection in a mouse model [33]. A griffithsin-CG combination provided synergistic protection against vaginal HPV infection in mice when they were dosed during and after 
HPV16 challenge [86]. In particular, a griffithsin-CG combination in the form of a fast-dissolving insert protected mice vaginally against HPV pseudovirus [80]. In clinical studies, the prevalence of HPV infection was lower in compliant CG users than compliant placebo users [114] (Table 13). When the CG gel was substituted for Sortilege during an internal digital examination, a significant decrease in HPV infection was observed [115]. As cytology screening in women induced a transient enhancement of HPV infection susceptibility, CG-based gel administration during examination might help mitigate this potential HPV infection enhancement induced by cytological screening [115]. CG treatment also lowered the number of HPV-infected participants [116]. In addition, CG gel administration accelerated the normal clearance of genital HPV infection in HPV-positive women [117]. All of these data suggest the superior antiviral potency of CGs in both animal and clinical studies.

Table 12. CG's in vivo anti-HPV activities in animal studies. (GFP, green fluorescence protein; RFP, red fluorescence protein; FDI, fast-dissolving insert; CVL, cervicovaginal lavage).

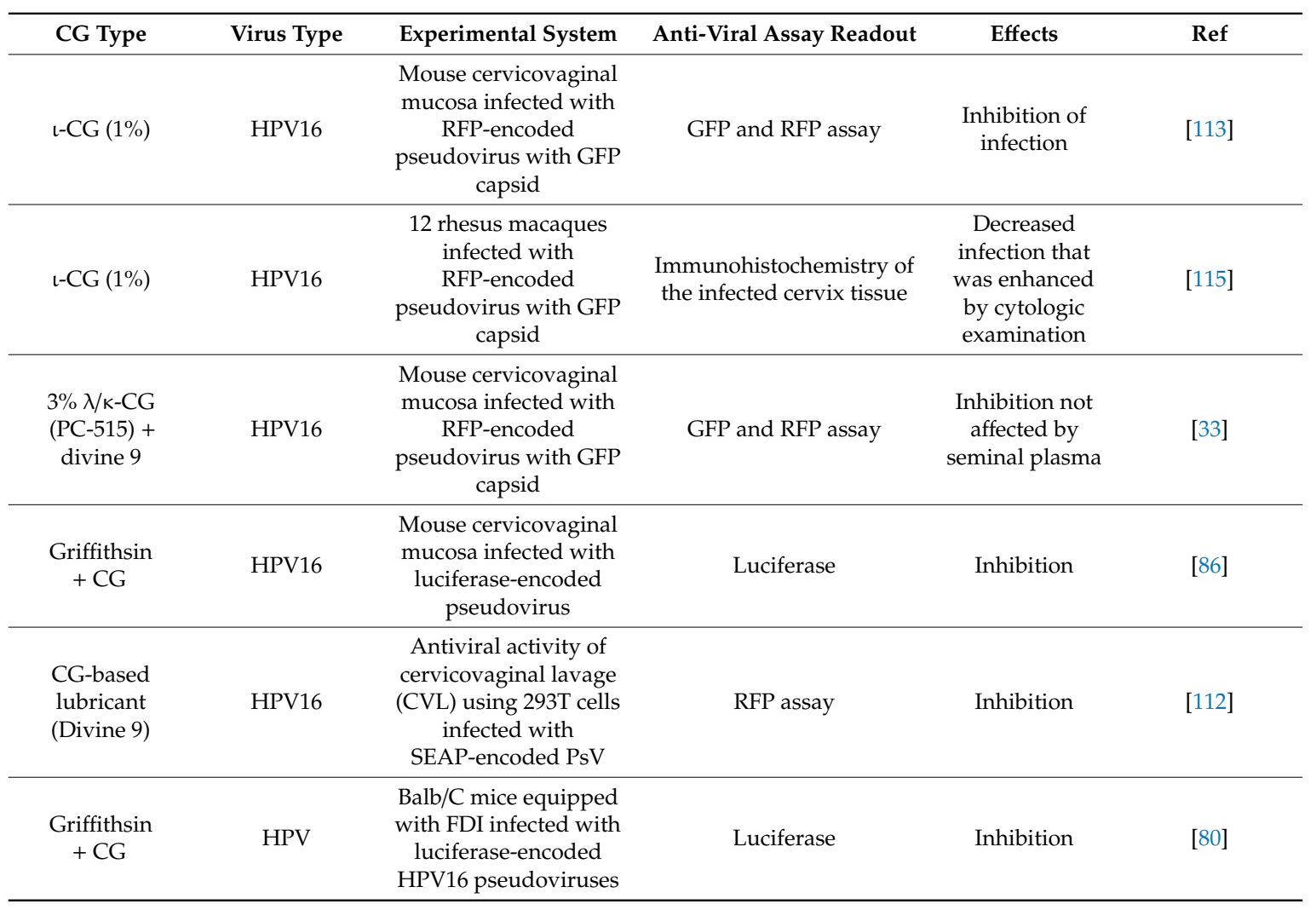

Table 13. CG's anti-HPV activities in clinical studies. (GFP, green fluorescence protein; RFP, red fluorescence protein; FDI, fast-dissolving insert; CVL, cervicovaginal lavage).

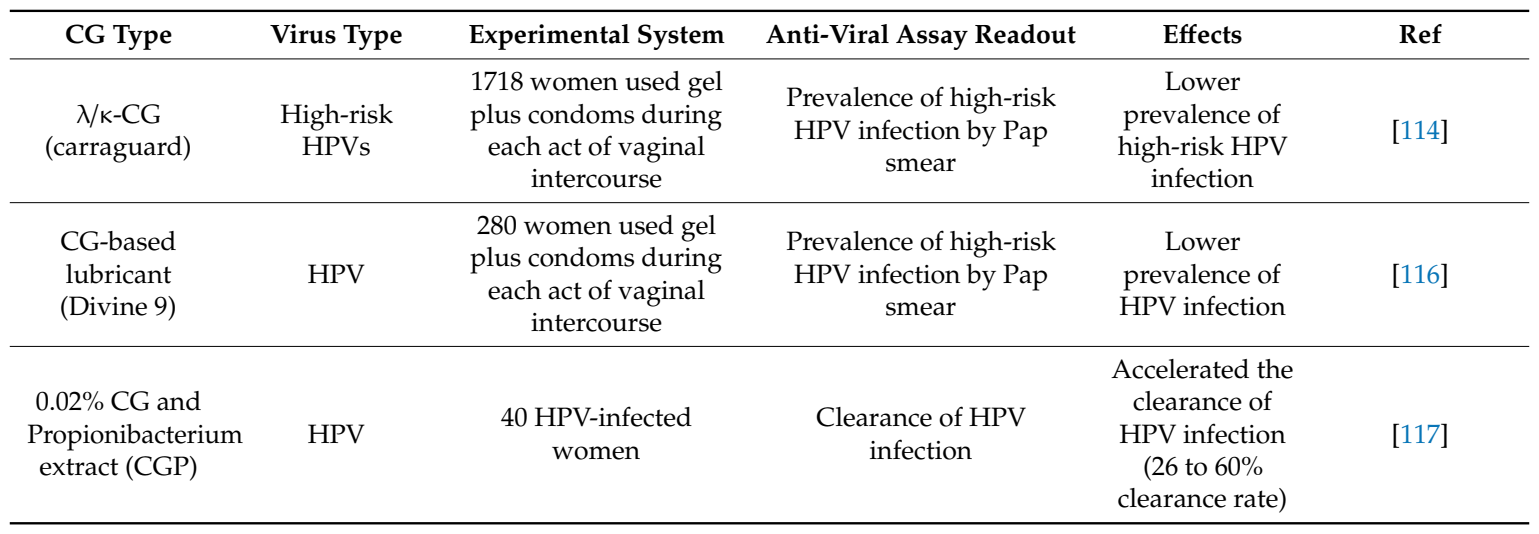




\section{Dengue Virus (DENV)}

Dengue virus (DENV) causes dengue fever, a mosquito-borne tropical disease. Five different in vitro studies reported CG antiviral activities against DENV using Vero, HepG2, foreskin PH, C6/356 HT mosquito, and BHK-21 cells $[16,29,36,38,39]$ (Table 14). $\lambda$-CG inhibitory activities against DENV infection result from dual interference with virus adsorption and internalization of the nucleocapsid into the cytoplasm [36]. More specifically, CG-treated DENV particles were not released from endosomes after entry [36]. However, I-CG failed to inhibit the adsorption of DENV to C6/36 HT mosquito cells [38]. This failure appeared to be related to the low presence of adequate heparan sulfate in C6/36 HT cell surfaces [38]. The development of CG resistance by DENV was also noticed after serial passaging in Vero cells. However, antiviral susceptibility was not altered in DENV propagated in C6/36 HT mosquito cells [16]. In particular, adsorption kinetics and internalization of resistant DENV variants in Vero cells was significantly diminished, but entry into C6/36 cells was unaffected [37]. A strong inhibitory CG effect was also confirmed by an antiviral assay that monitors cellular oxygen consumption rates [29].

Table 14. CG in vitro anti-DENV activities. (BHK-21 cells, baby hamster kidney 21 cells).

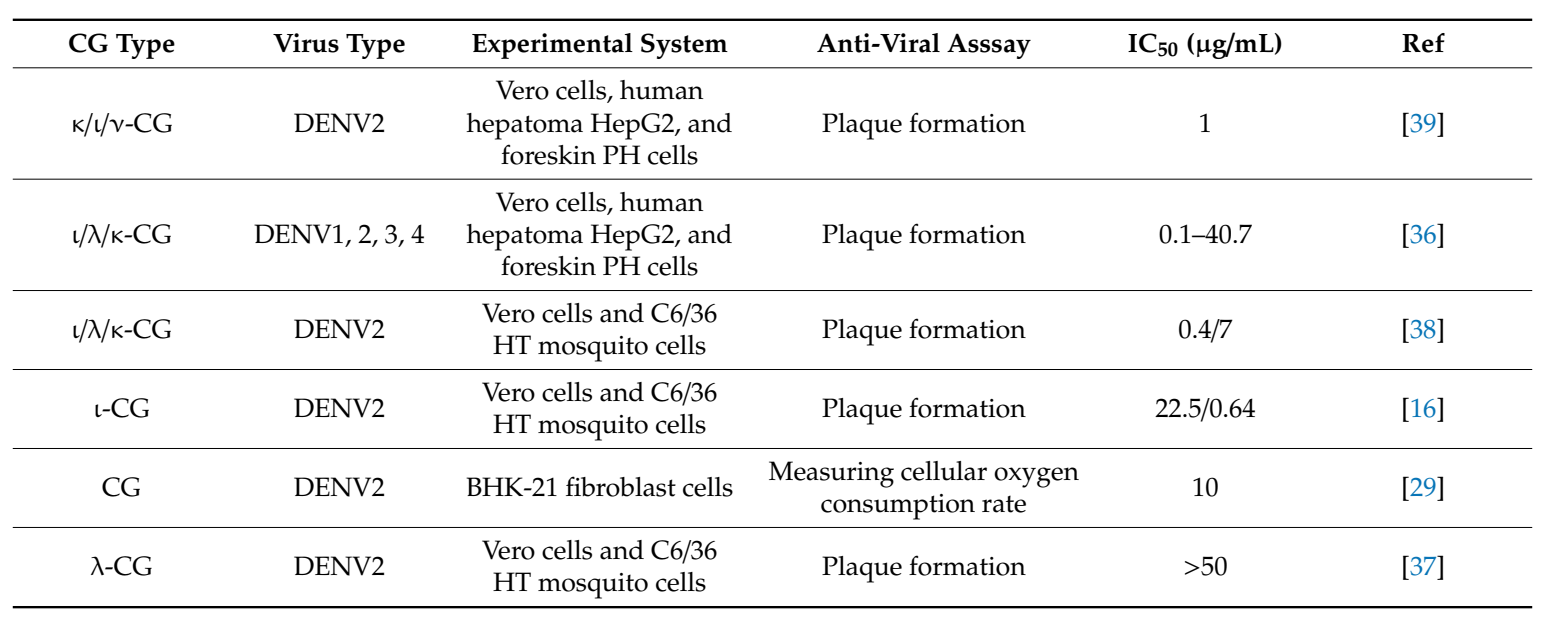

\section{Other Viruses}

Several studies have confirmed the in vitro antiviral activities of CGs against different kinds of viruses including adenovirus [18,118], African swine fever virus [27,35,83,118], arenavirus [17], chikungunya virus [19], coxsackievirus [18], Ebola virus [119], encephalomyocarditis virus [118], enterovirus [120,121], hantavirus [122], hepatitis A virus, measles virus [118], metapneumovirus [123], parainfluenza virus [18], poliovirus [18,118], rabies, reovirus [30], semliki forest virus [19,118], sindbis virus [18], scrapie [124], vaccinia virus [18,118], and vesicular stomatitis virus $[18,118]$ (Table 15). Their $\mathrm{IC}_{50}$ values ranged from 0.2 to $400 \mathrm{ug} / \mathrm{mL}$. 
Table 15. CG in vitro antiviral activities on other viruses. (N/D, not determined).

\begin{tabular}{|c|c|c|c|c|}
\hline Virus Type & CG Type & Cell Line & $\mathrm{IC}_{50}$ or $\mathrm{CPE}_{50}(\mu \mathrm{g} / \mathrm{mL})$ & Ref \\
\hline Adenovirus type 2 & $\mathrm{k}$ and $\lambda$ & Hela cells & $>200 />200$ & [18] \\
\hline Adenovirus type 5 & $\mathrm{\imath}$ & Hela cells & $>200$ & [118] \\
\hline $\begin{array}{l}\text { African swine fever } \\
\text { virus }\end{array}$ & $\iota$ & Vero cell & 10 & [118] \\
\hline $\begin{array}{l}\text { African swine fever } \\
\text { virus }\end{array}$ & $\iota$ & Vero cell & 50 & {$[35]$} \\
\hline $\begin{array}{l}\text { African swine fever } \\
\text { virus }\end{array}$ & $\kappa$ and $\lambda$ & Vero cell & $25 / 150$ & [27] \\
\hline Arenavirus & $\lambda$ & Vero cells & $0.2-0.3$ & [17] \\
\hline Chikungunya virus & $\iota$ & Vero cells & 3.8 & [19] \\
\hline $\begin{array}{l}\text { Cosackiesvirus } \\
\text { type B4 }\end{array}$ & $\mathrm{k}$ and $\lambda$ & Hela cells & $>400 />400$ & [18] \\
\hline Ebola virus & $\iota$ & Caco-2 cells & $\mathrm{N} / \mathrm{D}$ & [119] \\
\hline $\begin{array}{l}\text { Encephalomyocarditis } \\
\text { virus }\end{array}$ & $\iota$ & Not specified & 10 & [118] \\
\hline Enterovirus 71 & k & Vero cells & $10-100$ & [120] \\
\hline Enterovirus 71 & $\iota$ & Vero cells & 17.8 & [121] \\
\hline Hantavirus & $\iota$ & $\begin{array}{l}\text { Vero cells and } \\
\text { mouse } \\
\text { macrophages }\end{array}$ & & [122] \\
\hline Hepatitis A virus & $\mathrm{K}, \mathrm{l}$ and $\lambda$ & PLC/PRF/5 cells & $2.5,4.5$, and 100.3 & {$[28]$} \\
\hline Measles & $\iota$ & Not specified & $>200$ & [118] \\
\hline Metapneumoniavirus & $\iota$ & $\begin{array}{l}\text { Vero and human } \\
\text { bronchial epithelial } \\
\text { cells (BEAS-2B) }\end{array}$ & $0.1-1$ & [123] \\
\hline $\begin{array}{l}\text { Parainfluenza virus } \\
\text { type } 3\end{array}$ & $\mathrm{k}$ and $\lambda$ & Vero cells & $>40 />4$ & [18] \\
\hline Polio type 1 & ı & Hela cells & $>200$ & [118] \\
\hline Polio type 1 & $\mathrm{k}$ and $\lambda$ & Hela cells & $>400 />400$ & [18] \\
\hline Rabies & $\lambda$ P32 & BSR cells & $15-57$ & {$[30]$} \\
\hline Reovirus type 1 & $\mathrm{k}$ and $\lambda$ & Vero cells & $>40 />4$ & [18] \\
\hline $\begin{array}{l}\text { Semliki Forest } \\
\text { virus }\end{array}$ & $\iota$ & Vero cells & 0.7 & [19] \\
\hline $\begin{array}{l}\text { Semliki Forest } \\
\text { virus }\end{array}$ & $\iota$ & BHK-21 cells & 10 & [118] \\
\hline Sindbis virus & $\mathrm{k}$ and $\lambda$ & Vero cells & $7 / 2$ & [18] \\
\hline Scrapie & $\lambda$ type IV & $\begin{array}{c}\text { Female compton } \\
\text { mouse infected } \\
\text { with scrapie }\end{array}$ & inhibition of infection & [124] \\
\hline Vaccinia & $\iota$ & PPK cells & 10 & {$[118]$} \\
\hline Vaccinia & $\mathrm{k}$ and $\lambda$ & PPK cells & $36 / 16$ & [18] \\
\hline $\begin{array}{l}\text { Vesicular stomatitis } \\
\text { virus }\end{array}$ & $\iota$ & PRK cells & $>200$ & [118] \\
\hline $\begin{array}{l}\text { Vesicular stomatitis } \\
\text { virus }\end{array}$ & $\kappa$ and $\lambda$ & PRK cells & $0.3 / 0.2$ & [18] \\
\hline $\begin{array}{c}\text { Vesicular stomatitis } \\
\text { virus }\end{array}$ & $\kappa$ and $\lambda$ & Hela cells & $7 / 4$ & [18] \\
\hline
\end{tabular}




\section{Conclusions and Future Direction}

This review examined many of the pharmacological properties of CGs. They include in vitro and in vivo safety profiles; mechanisms of antiviral action; and in vitro and in vivo antiviral activities against HIV, HSV, respiratory viruses, HPV, DENV, and other viruses. Novel phenomena such as enhancement of HIV infectivity and development of CGs-resistant HSV variants found during development processes were also discussed. Despite the rather disappointing outcome of one clinical study, there still seem to be many desirable characteristics of microbicides that use CGs as the main pharmacological ingredient.

Due to the abundance of red algae as a natural resource, its production cost should be relatively low when compared to other chemically synthesized drugs. As a wide distribution of microbicides in the general public is necessary to efficiently prevent transmission of viral infections within society, the low production cost of CG-based microbicides would provide better access to these types of preventive measures.

Due to the broad antiviral spectrum of CGs [1-3,16], the use of CG-based microbicides may be the best prophylactic strategy in preventing multiple viral infections simultaneously. The versatile preventive capability of CGs could help suppress many clinically relevant STIs caused by HIV, HSV, and HPV. In addition to their superior antiviral activities against STIs, CGs also demonstrated highly effective inhibitory actions against respiratory viruses such as human rhinovirus, influenza virus, parainfluenza virus, coxsackievirus, and coronavirus, which are responsible for major, clinically-important respiratory infections [96,100-103]. As shown in Table 10, the clinical application of CG-based nasal sprays produced encouraging results. Considering the ongoing, world-wide COVID-19 pandemic severity, the use of CG-based nasal sprays might help mitigate the spread of coronavirus infections. The development of CG-based sprays as general disinfectants or virucides for public hygiene could be envisaged due to their extreme antiviral coverage.

The thousand-fold increase in their antiviral potency against HPV when compared to HIV and HSV highlights the possibility of developing CG-based microbicides that are specifically designed to prevent HPV infections. The use of CG-based gels could provide an on-demand, pre-exposure prophylactic option to those who are not vaccinated and want to protect themselves against HPV infection.

Numerous examples of successfully combining CGs with other antiviral drugs to synergistically block multiple viral infections emphasize their utility as an antiviral booster. As current anti-HIV drugs are not recommended for single preventive use due to the potential spread of drug resistance, a combination of CGs with anti-HIV drugs, such as AZT and MIV-150, may minimize drug resistance-associated problems.

Despite all of these advantages, there are still many challenges that need to be addressed to successfully develop CG-based microbicides. First, the reason why CG-based gels failed to prevent HIV transmission in clinical trials needs to be explored more thoroughly. Particularly, a more detailed pharmacokinetic study of CGs needs to be performed to exclude the possibility of insufficient CG delivery in target tissues as a contributing factor to the loss of CG-based gel antiviral activity. Also, CG-based gel clinical study designs need to be re-evaluated to ensure they do not affect the quality of the overall conclusions of such a clinical study. Second, HIV infection enhancement by CGs needs to be revisited. This seemingly paradoxical pro-viral action of CGs, specifically at low concentrations, needs to be explored in more detail experimentally and mechanistically. CG dose-dependent differential effects on the overall structures of virus particles and the efficiency of virus entry need to be studied at the molecular level. Neutralizing HIV infectivity enhancement by CGs via chemical alteration should be explored. Third, the molecular mechanism that causes the emergence of CG-resistant viral variants needs to be determined. In particular, genomic analyses of resistant variants should be performed to find potential relationships between specific viral genes and resistance development. The feasibility of delivering high concentrations of CGs to prevent the development of resistance also needs to be tested. Fourth, CG host-targeting antiviral modes of action such as disruption of host receptors and inhibition of intercellular virus transfer need to be studied in more detail. As viruses may be less 
prone to develop resistance to CG host-dependent antiviral activities, potentiating these CG virus entry-independent antiviral activities by chemical modification should be tested in the future.

To reassess the possibility of a second round of CG pharmacological development as a new class of preventive microbicides, all CG-based microbicide preclinical and clinical development processes were summarized and re-evaluated. Based on the strengths and weaknesses of CGs, the direction of a second CG development round was proposed. This bird's-eye view of the various pharmacological characteristics of CGs will help provide future research directions for the successful development of CG-based antimicrobial prophylactics.

Funding: This work was supported by the Dongguk University Research Fund of 2020.

Conflicts of Interest: The author declares that there are no competing interests regarding the publication of this paper.

\section{References}

1. Ahmadi, A.; Zorofchian Moghadamtousi, S.; Abubakar, S.; Zandi, K. Antiviral Potential of Algae Polysaccharides Isolated from Marine Sources: A Review. Biomed Res. Int. 2015, 2015, 825203. [CrossRef]

2. Damonte, E.B.; Matulewicz, M.C.; Cerezo, A.S. Sulfated seaweed polysaccharides as antiviral agents. Curr. Med. Chem. 2004, 11, 2399-2419. [CrossRef]

3. Witvrouw, M.; De Clercq, E. Sulfated polysaccharides extracted from sea algae as potential antiviral drugs. Gen. Pharmacol. 1997, 29, 497-511. [CrossRef]

4. Pirrone, V.; Wigdahl, B.; Krebs, F.C. The rise and fall of polyanionic inhibitors of the human immunodeficiency virus type 1. Antivir. Res. 2011, 90, 168-182. [CrossRef] [PubMed]

5. Tobacman, J.K. Review of harmful gastrointestinal effects of carrageenan in animal experiments. Environ. Health Perspect. 2001, 109, 983-994. [CrossRef] [PubMed]

6. Van de Wijgert, J.H.; Shattock, R.J. Vaginal microbicides: Moving ahead after an unexpected setback. AIDS 2007, 21, 2369-2376. [CrossRef] [PubMed]

7. Jean-Pierre, N.; Barnable, P.; Kizima, L.; Rodriguez, A.; Seidor, S.; Cooney, M.L.; Clark, M.R.; Doncel, G.F.; Robbiani, M.; Zydowsky, T.M.; et al. Multipurpose Prevention Approaches with Antiretroviral-Based Formulations. Antimicrob. Agents Chemother. 2016, 60, 1141-1144. [CrossRef]

8. Kenney, J.; Rodriguez, A.; Kizima, L.; Seidor, S.; Menon, R.; Jean-Pierre, N.; Pugach, P.; Levendosky, K.; Derby, N.; Gettie, A.; et al. A modified zinc acetate gel, a potential nonantiretroviral microbicide, is safe and effective against simian-human immunodeficiency virus and herpes simplex virus 2 infection in vivo. Antimicrob. Agents Chemother. 2013, 57, 4001-4009. [CrossRef]

9. Villegas, G.; Calenda, G.; Zhang, S.; Mizenina, O.; Kleinbeck, K.; Cooney, M.L.; Hoesley, C.J.; Creasy, G.W.; Friedland, B.; Fernandez-Romero, J.A.; et al. In Vitro Exposure to PC-1005 and Cervicovaginal Lavage Fluid from Women Vaginally Administered PC-1005 Inhibits HIV-1 and HSV-2 Infection in Human Cervical Mucosa. Antimicrob. Agents Chemother. 2016, 60, 5459-5466. [CrossRef]

10. Friend, D.R.; Clark, J.T.; Kiser, P.F.; Clark, M.R. Multipurpose prevention technologies: Products in development. Antivir. Res. 2013, 100, S39-S47. [CrossRef]

11. Skoler-Karpoff, S.; Ramjee, G.; Ahmed, K.; Altini, L.; Plagianos, M.G.; Friedland, B.; Govender, S.; De Kock, A.; Cassim, N.; Palanee, T.; et al. Efficacy of Carraguard for prevention of HIV infection in women in South Africa: A randomised, double-blind, placebo-controlled trial. Lancet 2008, 372, 1977-1987. [CrossRef]

12. Turville, S.G.; Aravantinou, M.; Miller, T.; Kenney, J.; Teitelbaum, A.; Hu, L.; Chudolij, A.; Zydowsky, T.M.; Piatak, M., Jr.; Bess, J.W., Jr; et al. Efficacy of Carraguard-based microbicides in vivo despite variable in vitro activity. PLoS ONE 2008, 3, e3162. [CrossRef]

13. Pirrone, V.; Passic, S.; Wigdahl, B.; Krebs, F.C. Application and removal of polyanionic microbicide compounds enhances subsequent infection by HIV-1. Virol. J. 2012, 9, 33. [CrossRef]

14. Tan, S.; Lu, L.; Li, L.; Liu, J.; Oksov, Y.; Lu, H.; Jiang, S.; Liu, S. Polyanionic candidate microbicides accelerate the formation of semen-derived amyloid fibrils to enhance HIV-1 infection. PLoS ONE 2013, 8, e59777. [CrossRef] [PubMed]

15. Tao, W.; Richards, C.; Hamer, D. Enhancement of HIV infection by cellulose sulfate. AIDS Res. Hum. Retrovir. 2008, 24, 925-929. [CrossRef] [PubMed] 
16. Acosta, E.G.; Piccini, L.E.; Talarico, L.B.; Castilla, V.; Damonte, E.B. Changes in antiviral susceptibility to entry inhibitors and endocytic uptake of dengue-2 virus serially passaged in Vero or C6/36 cells. Virus Res. 2014, 184, 39-43. [CrossRef]

17. Andrei, G.; De Clercq, E. Inhibitory effect of selected antiviral compounds on arenavirus replication in vitro. Antivir. Res. 1990, 14, 287-299. [CrossRef]

18. Baba, M.; Snoeck, R.; Pauwels, R.; de Clercq, E. Sulfated polysaccharides are potent and selective inhibitors of various enveloped viruses, including herpes simplex virus, cytomegalovirus, vesicular stomatitis virus, and human immunodeficiency virus. Antimicrob. Agents Chemother. 1988, 32, 1742-1745. [CrossRef]

19. Briolant, S.; Garin, D.; Scaramozzino, N.; Jouan, A.; Crance, J.M. In vitro inhibition of Chikungunya and Semliki Forest viruses replication by antiviral compounds: Synergistic effect of interferon-alpha and ribavirin combination. Antivir. Res. 2004, 61, 111-117. [CrossRef]

20. Buck, C.B.; Thompson, C.D.; Roberts, J.N.; Muller, M.; Lowy, D.R.; Schiller, J.T. Carrageenan is a potent inhibitor of papillomavirus infection. PLoS Pathog. 2006, 2, e69. [CrossRef]

21. Caceres, P.J.; Carlucci, M.J.; Damonte, E.B.; Matsuhiro, B.; Zuniga, E.A. Carrageenans from chilean samples of Stenogramme interrupta (Phyllophoraceae): Structural analysis and biological activity. Phytochemistry 2000, 53, 81-86. [CrossRef]

22. Carlucci, M.J.; Ciancia, M.; Matulewicz, M.C.; Cerezo, A.S.; Damonte, E.B. Antiherpetic activity and mode of action of natural carrageenans of diverse structural types. Antivir. Res. 1999, 43, 93-102. [CrossRef]

23. Carlucci, M.J.; Pujol, C.A.; Ciancia, M.; Noseda, M.D.; Matulewicz, M.C.; Damonte, E.B.; Cerezo, A.S. Antiherpetic and anticoagulant properties of carrageenans from the red seaweed Gigartina skottsbergii and their cyclized derivatives: Correlation between structure and biological activity. Int. J. Biol. Macromol. 1997, 20, 97-105. [CrossRef]

24. Carlucci, M.J.; Scolaro, L.A.; Damonte, E.B. Inhibitory action of natural carrageenans on Herpes simplex virus infection of mouse astrocytes. Chemotherapy 1999, 45, 429-436. [CrossRef] [PubMed]

25. Cosenza, V.A.; Navarro, D.A.; Pujol, C.A.; Damonte, E.B.; Stortz, C.A. Partial and total C-6 oxidation of gelling carrageenans. Modulation of the antiviral activity with the anionic character. Carbohydr. Polym. 2015, 128, 199-206. [CrossRef] [PubMed]

26. Diogo, J.V.; Novo, S.G.; Gonzalez, M.J.; Ciancia, M.; Bratanich, A.C. Antiviral activity of lambda-carrageenan prepared from red seaweed (Gigartina skottsbergii) against BoHV-1 and SuHV-1. Res. Vet. Sci. 2015, 98, 142-144. [CrossRef] [PubMed]

27. Garcia-Villalon, D.; Gil-Fernandez, C. Antiviral activity of sulfated polysaccharides against African swine fever virus. Antivir. Res. 1991, 15, 139-148. [CrossRef]

28. Girond, S.; Crance, J.M.; Van Cuyck-Gandre, H.; Renaudet, J.; Deloince, R. Antiviral activity of carrageenan on hepatitis A virus replication in cell culture. Res. Virol. 1991, 142, 261-270. [CrossRef]

29. Huang, S.H.; Lin, Y.S.; Wu, C.W.; Wu, C.J. Assessment of the inhibition of Dengue virus infection by carrageenan via real-time monitoring of cellular oxygen consumption rates within a microfluidic device. Biomicrofluidics 2014, 8, 024110. [CrossRef]

30. Luo, Z.; Tian, D.; Zhou, M.; Xiao, W.; Zhang, Y.; Li, M.; Sui, B.; Wang, W.; Guan, H.; Chen, H.; et al. lambda-Carrageenan P32 Is a Potent Inhibitor of Rabies Virus Infection. PLoS ONE 2015, 10, e0140586. [CrossRef]

31. Marchetti, M.; Pisani, S.; Pietropaolo, V.; Seganti, L.; Nicoletti, R.; Orsi, N. Inhibition of herpes simplex virus infection by negatively charged and neutral carbohydrate polymers. J. Chemother. 1995, 7, 90-96. [CrossRef] [PubMed]

32. Penuela, A.; Robledo, D.; Bourgougnon, N.; Bedoux, G.; Hernandez-Nunez, E.; Freile-Pelegrin, Y. Environmentally Friendly Valorization of Solieria filiformis (Gigartinales, Rhodophyta) from IMTA Using a Biorefinery Concept. Mar. Drugs 2018, 16, 487. [CrossRef] [PubMed]

33. Rodriguez, A.; Kleinbeck, K.; Mizenina, O.; Kizima, L.; Levendosky, K.; Jean-Pierre, N.; Villegas, G.; Ford, B.E.; Cooney, M.L.; Teleshova, N.; et al. In vitro and in vivo evaluation of two carrageenan-based formulations to prevent HPV acquisition. Antivir. Res. 2014, 108, 88-93. [CrossRef]

34. Shao, Q.; Guo, Q.; Xu, W.; Li, Z.; Zhao, T. Specific Inhibitory Effect of kappa-Carrageenan Polysaccharide on Swine Pandemic 2009 H1N1 Influenza Virus. PLoS ONE 2015, 10, e0126577.

35. Sola, A.; Rodriguez, S.; Gil-Fernandez, C.; Alarcon, B.; Gonzalez, M.E.; Carrasco, L. New agents active against African swine fever virus. Antimicrob. Agents Chemother. 1986, 29, 284-288. [CrossRef] 
36. Talarico, L.B.; Damonte, E.B. Interference in dengue virus adsorption and uncoating by carrageenans. Virology 2007, 363, 473-485. [CrossRef]

37. Talarico, L.B.; Damonte, E.B. Characterization of in vitro dengue virus resistance to carrageenan. J. Med. Virol. 2016, 88, 1120-1129. [CrossRef]

38. Talarico, L.B.; Noseda, M.D.; Ducatti, D.R.; Duarte, M.E.; Damonte, E.B. Differential inhibition of dengue virus infection in mammalian and mosquito cells by iota-carrageenan. J. Gen. Virol. 2011, 92 Pt 6, 1332-1342. [CrossRef]

39. Talarico, L.B.; Pujol, C.A.; Zibetti, R.G.; Faria, P.C.; Noseda, M.D.; Duarte, M.E.; Damonte, E.B. The antiviral activity of sulfated polysaccharides against dengue virus is dependent on virus serotype and host cell. Antivir. Res. 2005, 66, 103-110. [CrossRef]

40. Talarico, L.B.; Zibetti, R.G.; Faria, P.C.; Scolaro, L.A.; Duarte, M.E.; Noseda, M.D.; Pujol, C.A.; Damonte, E.B. Anti-herpes simplex virus activity of sulfated galactans from the red seaweeds Gymnogongrus griffithsiae and Cryptonemia crenulata. Int. J. Biol. Macromol. 2004, 34, 63-71. [CrossRef]

41. Vlieghe, P.; Clerc, T.; Pannecouque, C.; Witvrouw, M.; De Clercq, E.; Salles, J.P.; Kraus, J.L. Synthesis of new covalently bound kappa-carrageenan-AZT conjugates with improved anti-HIV activities. J. Med. Chem. 2002, 45, 1275-1283. [CrossRef] [PubMed]

42. Wang, W.; Zhang, P.; Hao, C.; Zhang, X.E.; Cui, Z.Q.; Guan, H.S. In vitro inhibitory effect of carrageenan oligosaccharide on influenza A H1N1 virus. Antivir. Res. 2011, 92, 237-246. [CrossRef] [PubMed]

43. Abu-Galiyun, E.; Huleihel, M.; Levy-Ontman, O. Antiviral bioactivity of renewable polysaccharides against Varicella Zoster. Cell Cycle 2019, 18, 3540-3549. [CrossRef] [PubMed]

44. Elias, C.J.; Coggins, C.; Alvarez, F.; Brache, V.; Fraser, I.S.; Lacarra, M.; Lahteenmaki, P.; Massai, R.; Mishell, D.R., Jr.; Phillips, D.M.; et al. Colposcopic evaluation of a vaginal gel formulation of iota-carrageenan. Contraception 1997, 56, 387-389. [CrossRef]

45. Kilmarx, P.H.; Blanchard, K.; Chaikummao, S.; Friedland, B.A.; Srivirojana, N.; Connolly, C.; Witwatwongwana, P.; Supawitkul, S.; Mock, P.A.; Chaowanachan, T.; et al. A randomized, placebo-controlled trial to assess the safety and acceptability of use of carraguard vaginal gel by heterosexual couples in Thailand. Sex. Transm. Dis. 2008, 35, 226-232. [CrossRef]

46. Van de Wijgert, J.H.; Braunstein, S.L.; Morar, N.S.; Jones, H.E.; Madurai, L.; Strickfaden, T.T.; Moodley, M.; Aboobaker, J.; Ndlovu, G.; Ferguson, T.M.; et al. Carraguard Vaginal Gel Safety in HIV-Positive Women and Men in South Africa. J. Acquir. Immune Defic. Syndr. 2007, 46, 538-546. [CrossRef]

47. Bollen, L.J.; Blanchard, K.; Kilmarx, P.H.; Chaikummao, S.; Connolly, C.; Wasinrapee, P.; Srivirojana, N.; Achalapong, J.; Tappero, J.W.; McNicholl, J.M. No increase in cervicovaginal proinflammatory cytokines after Carraguard use in a placebo-controlled randomized clinical trial. J. Acquir. Immune Defic. Syndr. 2008, 47, 253-257. [CrossRef]

48. Whitehead, S.J.; Kilmarx, P.H.; Blanchard, K.; Manopaiboon, C.; Chaikummao, S.; Friedland, B.; Achalapong, J.; Wankrairoj, M.; Mock, P.; Thanprasertsuk, S.; et al. Acceptability of Carraguard vaginal gel use among Thai couples. AIDS 2006, 20, 2141-2148. [CrossRef]

49. Friedland, B.A.; Hoesley, C.J.; Plagianos, M.; Hoskin, E.; Zhang, S.; Teleshova, N.; Alami, M.; Novak, L.; Kleinbeck, K.R.; Katzen, L.L.; et al. First-in-Human Trial of MIV-150 and Zinc Acetate Coformulated in a Carrageenan Gel: Safety, Pharmacokinetics, Acceptability, Adherence, and Pharmacodynamics. J. Acquir. Immune Defic. Syndr. 2016, 73, 489-496. [CrossRef]

50. McLean, C.A.; van de Wijgert, J.H.; Jones, H.E.; Karon, J.M.; McNicoll, J.M.; Whitehead, S.J.; Braunstein, S.; Achalapong, J.; Chaikummao, S.; Tappero, J.W.; et al. HIV genital shedding and safety of Carraguard use by HIV-infected women: A crossover trial in Thailand. AIDS 2010, 24, 717-722. [CrossRef]

51. Kilmarx, P.H.; van de Wijgert, J.H.; Chaikummao, S.; Jones, H.E.; Limpakarnjanarat, K.; Friedland, B.A.; Karon, J.M.; Manopaiboon, C.; Srivirojana, N.; Yanpaisarn, S.; et al. Safety and acceptability of the candidate microbicide Carraguard in Thai Women: Findings from a Phase II Clinical Trial. J. Acquir. Immune Defic. Syndr. 2006, 43, 327-334. [CrossRef] [PubMed]

52. Ramjee, G.; Morar, N.S.; Braunstein, S.; Friedland, B.; Jones, H.; van de Wijgert, J. Acceptability of Carraguard, a candidate microbicide and methyl cellulose placebo vaginal gels among HIV-positive women and men in Durban, South Africa. AIDS Res. Ther. 2007, 4, 20. [CrossRef] [PubMed]

53. Carraguard Phase II South Africa Study Team. Expanded safety and acceptability of the candidate vaginal microbicide Carraguard(R) in South Africa. Contraception 2010, 82, 563-571. [CrossRef] [PubMed] 
54. Whitehead, S.J.; McLean, C.; Chaikummao, S.; Braunstein, S.; Utaivoravit, W.; van de Wijgert, J.H.; Mock, P.A.; Siraprapasiri, T.; Friedland, B.A.; Kilmarx, P.H.; et al. Acceptability of Carraguard vaginal microbicide gel among HIV-infected women in Chiang Rai, Thailand. PLoS ONE 2011, 6, e14831. [CrossRef]

55. Pearce-Pratt, R.; Phillips, D.M. Sulfated polysaccharides inhibit lymphocyte-to-epithelial transmission of human immunodeficiency virus-1. Biol. Reprod. 1996, 54, 173-182. [CrossRef]

56. Lynch, G.; Low, L.; Li, S.; Sloane, A.; Adams, S.; Parish, C.; Kemp, B.; Cunningham, A.L. Sulfated polyanions prevent HIV infection of lymphocytes by disruption of the CD4-gp120 interaction, but do not inhibit monocyte infection. J. Leukoc. Biol. 1994, 56, 266-272. [CrossRef]

57. Schaeffer, D.J.; Krylov, V.S. Anti-HIV activity of extracts and compounds from algae and cyanobacteria. Ecotoxicol. Environ. Saf. 2000, 45, 208-227. [CrossRef]

58. Ghosh, T.; Chattopadhyay, K.; Marschall, M.; Karmakar, P.; Mandal, P.; Ray, B. Focus on antivirally active sulfated polysaccharides: From structure-activity analysis to clinical evaluation. Glycobiology 2009, 19, 2-15. [CrossRef]

59. Wang, W.; Wang, S.X.; Guan, H.S. The antiviral activities and mechanisms of marine polysaccharides: An overview. Mar. Drugs 2012, 10, 2795-2816. [CrossRef]

60. Arad, S.M.; Levy-Ontman, O. Red microalgal cell-wall polysaccharides: Biotechnological aspects. Curr. Opin. Biotechnol. 2010, 21, 358-364. [CrossRef]

61. Nakashima, H.; Kido, Y.; Kobayashi, N.; Motoki, Y.; Neushul, M.; Yamamoto, N. Purification and characterization of an avian myeloblastosis and human immunodeficiency virus reverse transcriptase inhibitor, sulfated polysaccharides extracted from sea algae. Antimicrob. Agents Chemother. 1987, 31, 1524-1528. [CrossRef] [PubMed]

62. Hamasuna, R.; Eizuru, Y.; Minamishima, Y. Inhibition by iota-carrageenan of the spread of murine cytomegalovirus from the peritoneal cavity to the blood plasma. J. Gen. Virol. 1994, 75 Pt 1, 111-116. [CrossRef]

63. Hamasuna, R.E.; Shishime, Y.; Minamishima, Y. Protective effect of carrageenan against murine cytomegalovirus infection in mice. Antimicrob. Agents Chemother. 1993, 4, 353-360. [CrossRef]

64. Abdool Karim, Q.; Abdool Karim, S.S.; Frohlich, J.A.; Grobler, A.C.; Baxter, C.; Mansoor, L.E.; Kharsany, A.B.; Sibeko, S.; Mlisana, K.P.; Omar, Z.; et al. Effectiveness and safety of tenofovir gel, an antiretroviral microbicide, for the prevention of HIV infection in women. Science 2010, 329, 1168-1174. [CrossRef]

65. Berry, M.; Wirtz, A.L.; Janayeva, A.; Ragoza, V.; Terlikbayeva, A.; Amirov, B.; Baral, S.; Beyrer, C. Risk factors for HIV and unprotected anal intercourse among men who have sex with men (MSM) in Almaty, Kazakhstan. PLoS ONE 2012, 7, e43071. [CrossRef] [PubMed]

66. Yamada, T.; Ogamo, A.; Saito, T.; Watanabe, J.; Uchiyama, H.; Nakagawa, Y. Preparation and anti-HIV activity of low molecular-weight carrageenans and their sulfated derivatives. Carbohydr. Polym. 1997, 32, 51-55. [CrossRef]

67. Fernandez-Romero, J.A.; Thorn, M.; Turville, S.G.; Titchen, K.; Sudol, K.; Li, J.; Miller, T.; Robbiani, M.; Maguire, R.A.; Buckheit, R.W., Jr.; et al. Carrageenan/MIV-150 (PC-815), a combination microbicide. Sex. Transm. Dis. 2007, 34, 9-14. [CrossRef]

68. Ding, J.; Rapista, A.; Teleshova, N.; Lu, W.; Klotman, M.E.; Chang, T.L. Mucosal human defensins 5 and 6 antagonize the anti-HIV activity of candidate polyanion microbicides. J. Innate Immun. 2011, 3, $208-212$. [CrossRef]

69. Barnable, P.; Calenda, G.; Ouattara, L.; Gettie, A.; Blanchard, J.; Jean-Pierre, N.; Kizima, L.; Rodriguez, A.; Abraham, C.; Menon, R.; et al. A MIV-150/zinc acetate gel inhibits SHIV-RT infection in macaque vaginal explants. PLoS ONE 2014, 9, e108109. [CrossRef]

70. Barnable, P.; Calenda, G.; Bonnaire, T.; Menon, R.; Levendosky, K.; Gettie, A.; Blanchard, J.; Cooney, M.L.; Fernandez-Romero, J.A.; Zydowsky, T.M.; et al. MIV-150/zinc acetate gel inhibits cell-associated simian-human immunodeficiency virus reverse transcriptase infection in a macaque vaginal explant model. Antimicrob. Agents Chemother. 2015, 59, 3829-3837. [CrossRef]

71. Cummins, J.E., Jr.; Guarner, J.; Flowers, L.; Guenthner, P.C.; Bartlett, J.; Morken, T.; Grohskopf, L.A.; Paxton, L.; Dezzutti, C.S. Preclinical testing of candidate topical microbicides for anti-human immunodeficiency virus type 1 activity and tissue toxicity in a human cervical explant culture. Antimicrob. Agents Chemother. 2007, 51, 1770-1779. [CrossRef] [PubMed] 
72. Perotti, M.E.; Pirovano, A.; Phillips, D.M. Carrageenan formulation prevents macrophage trafficking from vagina: Implications for microbicide development. Biol. Reprod. 2003, 69, 933-939. [CrossRef] [PubMed]

73. Kenney, J.; Aravantinou, M.; Singer, R.; Hsu, M.; Rodriguez, A.; Kizima, L.; Abraham, C.J.; Menon, R.; Seidor, S.; Chudolij, A.; et al. An antiretroviral/zinc combination gel provides 24 hours of complete protection against vaginal SHIV infection in macaques. PLoS ONE 2011, 6, e15835. [CrossRef] [PubMed]

74. Singer, R.; Derby, N.; Rodriguez, A.; Kizima, L.; Kenney, J.; Aravantinou, M.; Chudolij, A.; Gettie, A.; Blanchard, J.; Lifson, J.D.; et al. The nonnucleoside reverse transcriptase inhibitor MIV-150 in carrageenan gel prevents rectal transmission of simian/human immunodeficiency virus infection in macaques. J. Virol. 2011, 85, 5504-5512. [CrossRef] [PubMed]

75. Kenney, J.; Singer, R.; Derby, N.; Aravantinou, M.; Abraham, C.J.; Menon, R.; Seidor, S.; Zhang, S.; Gettie, A.; Blanchard, J.; et al. A single dose of a MIV-150/Zinc acetate gel provides $24 \mathrm{~h}$ of protection against vaginal simian human immunodeficiency virus reverse transcriptase infection, with more limited protection rectally 8-24 h after gel use. AIDS Res. Hum. Retrovir. 2012, 28, 1476-1484. [CrossRef]

76. Halpern, V.; Ogunsola, F.; Obunge, O.; Wang, C.H.; Onyejepu, N.; Oduyebo, O.; Taylor, D.; McNeil, L.; Mehta, N.; Umo-Otong, J.; et al. Effectiveness of cellulose sulfate vaginal gel for the prevention of HIV infection: Results of a Phase III trial in Nigeria. PLoS ONE 2008, 3, e3784. [CrossRef]

77. Van Damme, L.; Govinden, R.; Mirembe, F.M.; Guedou, F.; Solomon, S.; Becker, M.L.; Pradeep, B.S.; Krishnan, A.K.; Alary, M.; Pande, B.; et al. Lack of effectiveness of cellulose sulfate gel for the prevention of vaginal HIV transmission. N. Engl. J. Med. 2008, 359, 463-472. [CrossRef]

78. Roan, N.R.; Munch, J.; Arhel, N.; Mothes, W.; Neidleman, J.; Kobayashi, A.; Smith-McCune, K.; Kirchhoff, F.; Greene, W.C. The cationic properties of SEVI underlie its ability to enhance human immunodeficiency virus infection. J. Virol. 2009, 83, 73-80. [CrossRef]

79. Munch, J.; Rucker, E.; Standker, L.; Adermann, K.; Goffinet, C.; Schindler, M.; Wildum, S.; Chinnadurai, R.; Rajan, D.; Specht, A.; et al. Semen-derived amyloid fibrils drastically enhance HIV infection. Cell 2007, 131, 1059-1071. [CrossRef]

80. Derby, N.; Lal, M.; Aravantinou, M.; Kizima, L.; Barnable, P.; Rodriguez, A.; Lai, M.; Wesenberg, A.; Ugaonkar, S.; Levendosky, K.; et al. Griffithsin carrageenan fast dissolving inserts prevent SHIV HSV-2 and HPV infections in vivo. Nat. Commun. 2018, 9, 3881. [CrossRef]

81. Zeitlin, L.; Whaley, K.J.; Hegarty, T.A.; Moench, T.R.; Cone, R.A. Tests of vaginal microbicides in the mouse genital herpes model. Contraception 1997, 56, 329-333. [CrossRef]

82. Bourne, K.Z.; Bourne, N.; Reising, S.F.; Stanberry, L.R. Plant products as topical microbicide candidates: Assessment of in vitro and in vivo activity against herpes simplex virus type 2. Antivir. Res. 1999, 42, 219-226. [CrossRef]

83. Gonzalez, M.E.; Carrasco, L. Animal viruses promote the entry of polysaccharides with antiviral activity into cells. Biochem. Biophys. Res. Commun. 1987, 146, 1303-1310. [CrossRef]

84. Carlucci, M.J.; Scolaro, L.A.; Noseda, M.D.; Cerezo, A.S.; Damonte, E.B. Protective effect of a natural carrageenan on genital herpes simplex virus infection in mice. Antivir. Res. 2004, 64, 137-141. [CrossRef]

85. Fernandez-Romero, J.A.; Abraham, C.J.; Rodriguez, A.; Kizima, L.; Jean-Pierre, N.; Menon, R.; Begay, O.; Seidor, S.; Ford, B.E.; Gil, P.I.; et al. Zinc acetate/carrageenan gels exhibit potent activity in vivo against high-dose herpes simplex virus 2 vaginal and rectal challenge. Antimicrob. Agents Chemother. 2012, 56, 358-368. [CrossRef]

86. Levendosky, K.; Mizenina, O.; Martinelli, E.; Jean-Pierre, N.; Kizima, L.; Rodriguez, A.; Kleinbeck, K.; Bonnaire, T.; Robbiani, M.; Zydowsky, T.M.; et al. Griffithsin and Carrageenan Combination To Target Herpes Simplex Virus 2 and Human Papillomavirus. Antimicrob. Agents Chemother. 2015, 59, 7290-7298. [CrossRef]

87. Maguire, R.A.; Bergman, N.; Phillips, D.M. Comparison of microbicides for efficacy in protecting mice against vaginal challenge with herpes simplex virus type 2, cytotoxicity, antibacterial properties, and sperm immobilization. Sex. Transm. Dis. 2001, 28, 259-265. [CrossRef]

88. Stiles, J.; Guptill-Yoran, L.; Moore, G.E.; Pogranichniy, R.M. Effects of lambda-carrageenan on in vitro replication of feline herpesvirus and on experimentally induced herpetic conjunctivitis in cats. Investig. Ophthalmol. Vis. Sci. 2008, 49, 1496-1501. [CrossRef]

89. Zacharopoulos, V.R.; Phillips, D.M. Vaginal formulations of carrageenan protect mice from herpes simplex virus infection. Clin. Diagn. Lab. Immunol. 1997, 4, 465-468. [CrossRef] 
90. Maguire, R.A.; Zacharopoulos, V.R.; Phillips, D.M. Carrageenan-based nonoxynol-9 spermicides for prevention of sexually transmitted infections. Sex. Transm. Dis. 1998, 25, 494-500. [CrossRef]

91. Carlucci, M.J.; Scolaro, L.A.; Damonte, E.B. Herpes simplex virus type 1 variants arising after selection with an antiviral carrageenan: Lack of correlation between drug susceptibility and syn phenotype. J. Med. Virol. 2002, 68, 92-98. [CrossRef]

92. Mateu, C.G.; Perez Recalde, M.; Artuso, M.C.; Hermida, G.; Linero, F.N.; Scolaro, L.A.; Damonte, E.B.; Pujol, C.A.; Carlucci, M.J. Emergence of Herpes Simplex Virus-1 Syncytial Variants With Altered Virulence for Mice After Selection With a Natural Carrageenan. Sex. Transm. Dis. 2011, 38, 555-561. [CrossRef] [PubMed]

93. Carolina Artuso, M.; Linero, F.N.; Gazzaniga, S.; Scolaro, L.A.; Pujol, C.A.; Wainstok, R.; Josefina Carlucci, M. Altered expression of cytokines in mice infected intranasally with two syncytial variants of Herpes simplex virus type 1. Microb. Pathog. 2014, 71, 68-72. [CrossRef] [PubMed]

94. Graf, C.; Bernkop-Schnurch, A.; Egyed, A.; Koller, C.; Prieschl-Grassauer, E.; Morokutti-Kurz, M. Development of a nasal spray containing xylometazoline hydrochloride and iota-carrageenan for the symptomatic relief of nasal congestion caused by rhinitis and sinusitis. Int. J. Gen. Med. 2018, 11, 275-283. [CrossRef]

95. Grassauer, A.; Weinmuellner, R.; Meier, C.; Pretsch, A.; Prieschl-Grassauer, E.; Unger, H. Iota-Carrageenan is a potent inhibitor of rhinovirus infection. Virol. J. 2008, 5, 107. [CrossRef] [PubMed]

96. Leibbrandt, A.; Meier, C.; Konig-Schuster, M.; Weinmullner, R.; Kalthoff, D.; Pflugfelder, B.; Graf, P.; Frank-Gehrke, B.; Beer, M.; Fazekas, T.; et al. Iota-carrageenan is a potent inhibitor of influenza A virus infection. PLoS ONE 2010, 5, e14320. [CrossRef] [PubMed]

97. Morokutti-Kurz, M.; Graf, C.; Prieschl-Grassauer, E. Amylmetacresol/2,4-dichlorobenzyl alcohol, hexylresorcinol, or carrageenan lozenges as active treatments for sore throat. Int. J. Gen. Med. 2017, 10, 53-60. [CrossRef] [PubMed]

98. Morokutti-Kurz, M.; Konig-Schuster, M.; Koller, C.; Graf, C.; Graf, P.; Kirchoff, N.; Reutterer, B.; Seifert, J.M.; Unger, H.; Grassauer, A.; et al. The Intranasal Application of Zanamivir and Carrageenan Is Synergistically Active against Influenza A Virus in the Murine Model. PLoS ONE 2015, 10, e0128794. [CrossRef]

99. Yu, G.; Li, M.; Wang, W.; Liu, X.; Zhao, X.; Lv, Y.; Li, G.; Jiao, G.; Zhao, X. Structure and anti-influenza A (H1N1) virus activity of three polysaccharides from Eucheuma denticulatum. J. Ocean Univ. China 2012, 11, 527-532. [CrossRef]

100. Fujisawa, H.; Tsuru, S.; Taniguchi, M.; Zinnaka, Y.; Nomoto, K. Protective mechanisms against pulmonary infection with influenza virus. I. Relative contribution of polymorphonuclear leukocytes and of alveolar macrophages to protection during the early phase of intranasal infection. J. Gen. Virol. 1987, 68 Pt 2, 425-432. [CrossRef]

101. Tang, F.; Chen, F.; Li, F. Preparation and potentialin vivoanti-influenza virus activity of low molecular-weight K-carrageenans and their derivatives. J. Appl. Polym. Sci. 2013, 127, 2110-2115. [CrossRef]

102. Tsuru, S.; Fujisawa, H.; Taniguchi, M.; Zinnaka, Y.; Nomoto, K. Mechanism of protection during the early phase of a generalized viral infection. II. Contribution of polymorphonuclear leukocytes to protection against intravenous infection with influenza virus. J. Gen. Virol. 1987, 68 Pt 2, 419-424. [CrossRef]

103. Tsuru, S.; Kitani, H.; Seno, M.; Abe, M.; Zinnaka, Y.; Nomoto, K. Mechanism of protection during the early phase of a generalized viral infection. I. Contribution of phagocytes to protection against ectromelia virus. J. Gen. Virol. 1983, 64 Pt 9, 2021-2026. [CrossRef] [PubMed]

104. Hebar, A.; Koller, C.; Seifert, J.M.; Chabicovsky, M.; Bodenteich, A.; Bernkop-Schnurch, A.; Grassauer, A.; Prieschl-Grassauer, E. Non-clinical safety evaluation of intranasal iota-carrageenan. PLoS ONE 2015, 10, e0122911. [CrossRef] [PubMed]

105. Eccles, R.; Meier, C.; Jawad, M.; Weinmullner, R.; Grassauer, A.; Prieschl-Grassauer, E. Efficacy and safety of an antiviral Iota-Carrageenan nasal spray: A randomized, double-blind, placebo-controlled exploratory study in volunteers with early symptoms of the common cold. Respir. Res. 2010, 11, 108. [CrossRef] [PubMed]

106. Fazekas, T.; Eickhoff, P.; Pruckner, N.; Vollnhofer, G.; Fischmeister, G.; Diakos, C.; Rauch, M.; Verdianz, M.; Zoubek, A.; Gadner, H.; et al. Lessons learned from a double-blind randomised placebo-controlled study with a iota-carrageenan nasal spray as medical device in children with acute symptoms of common cold. BMC Complement. Altern. Med. 2012, 12, 147. [CrossRef] 
107. Ludwig, M.; Enzenhofer, E.; Schneider, S.; Rauch, M.; Bodenteich, A.; Neumann, K.; Prieschl-Grassauer, E.; Grassauer, A.; Lion, T.; Mueller, C.A. Efficacy of a carrageenan nasal spray in patients with common cold: A randomized controlled trial. Respir. Res. 2013, 14, 124. [CrossRef]

108. Koenighofer, M.; Lion, T.; Bodenteich, A.; Prieschl-Grassauer, E.; Grassauer, A.; Unger, H.; Mueller, C.A.; Fazekas, T. Carrageenan nasal spray in virus confirmed common cold: Individual patient data analysis of two randomized controlled trials. Multidiscip. Respir. Med. 2014, 9, 57. [CrossRef]

109. Eccles, R.; Winther, B.; Johnston, S.L.; Robinson, P.; Trampisch, M.; Koelsch, S. Efficacy and safety of iota-carrageenan nasal spray versus placebo in early treatment of the common cold in adults: The ICICC trial. Respir. Res. 2015, 16, 121. [CrossRef]

110. Kines, R.C.; Cerio, R.J.; Roberts, J.N.; Thompson, C.D.; de Los Pinos, E.; Lowy, D.R.; Schiller, J.T. Human papillomavirus capsids preferentially bind and infect tumor cells. Int. J. Cancer 2016, 138, 901-911. [CrossRef]

111. Wang, J.W.; Jagu, S.; Kwak, K.; Wang, C.; Peng, S.; Kirnbauer, R.; Roden, R.B. Preparation and properties of a papillomavirus infectious intermediate and its utility for neutralization studies. Virology 2014, 449, 304-316. [CrossRef] [PubMed]

112. Novetsky, A.P.; Keller, M.J.; Gradissimo, A.; Chen, Z.; Morgan, S.L.; Xue, X.; Strickler, H.D.; Fernandez-Romero, J.A.; Burk, R.; Einstein, M.H. In vitro inhibition of human papillomavirus following use of a carrageenan-containing vaginal gel. Gynecol. Oncol. 2016, 143, 313-318. [CrossRef]

113. Roberts, J.N.; Buck, C.B.; Thompson, C.D.; Kines, R.; Bernardo, M.; Choyke, P.L.; Lowy, D.R.; Schiller, J.T. Genital transmission of HPV in a mouse model is potentiated by nonoxynol-9 and inhibited by carrageenan. Nat. Med. 2007, 13, 857-861. [CrossRef] [PubMed]

114. Marais, D.; Gawarecki, D.; Allan, B.; Ahmed, K.; Altini, L.; Cassim, N.; Gopolang, F.; Hoffman, M.; Ramjee, G.; Williamson, A.L. The effectiveness of Carraguard, a vaginal microbicide, in protecting women against high-risk human papillomavirus infection. Antivir. Ther. 2011, 16, 1219-1226. [CrossRef]

115. Roberts, J.N.; Kines, R.C.; Katki, H.A.; Lowy, D.R.; Schiller, J.T. Effect of Pap smear collection and carrageenan on cervicovaginal human papillomavirus-16 infection in a rhesus macaque model. J. Natl. Cancer Inst. 2011, 103, 737-743. [CrossRef] [PubMed]

116. Magnan, S.; Tota, J.E.; El-Zein, M.; Burchell, A.N.; Schiller, J.T.; Ferenczy, A.; Tellier, P.P.; Coutlee, F.; Franco, E.L.; Group, C.S. Efficacy of a Carrageenan gel Against Transmission of Cervical HPV (CATCH): Interim analysis of a randomized, double-blind, placebo-controlled, phase 2B trial. Clin. Microbiol. Infect. 2019, 25, 210-216. [CrossRef]

117. Perino, A.; Consiglio, P.; Maranto, M.; De Franciscis, P.; Marci, R.; Restivo, V.; Manzone, M.; Capra, G.; Cucinella, G.; Calagna, G. Impact of a new carrageenan-based vaginal microbicide in a female population with genital HPV-infection: First experimental results. Eur. Rev. Med. Pharmacol. Sci. 2019, 23, 6744-6752.

118. Gonzalez, M.E.; Alarcon, B.; Carrasco, L. Polysaccharides as antiviral agents: Antiviral activity of carrageenan. Antimicrob. Agents Chemother. 1987, 31, 1388-1393. [CrossRef]

119. Tamhankar, M.; Gerhardt, D.M.; Bennett, R.S.; Murphy, N.; Jahrling, P.B.; Patterson, J.L. Heparan sulfate is an important mediator of Ebola virus infection in polarized epithelial cells. Virol. J. 2018, 15, 135. [CrossRef]

120. Chiu, Y.H.; Chan, Y.L.; Tsai, L.W.; Li, T.L.; Wu, C.J. Prevention of human enterovirus 71 infection by kappa carrageenan. Antivir. Res. 2012, 95, 128-134. [CrossRef]

121. Tseligka, E.D.; Sobo, K.; Stoppini, L.; Cagno, V.; Abdul, F.; Piuz, I.; Meylan, P.; Huang, S.; Constant, S.; Tapparel, C. A VP1 mutation acquired during an enterovirus 71 disseminated infection confers heparan sulfate binding ability and modulates ex vivo tropism. PLoS Pathog. 2018, 14, e1007190. [CrossRef] [PubMed]

122. Pavliga, S.N.; Kompanets, G.G.; Tsygankov, V.Y. The Experimental Research (In Vitro) of Carrageenans and Fucoidans to Decrease Activity of Hantavirus. Food Environ. Virol. 2016, 8, 120-124. [CrossRef] [PubMed]

123. Klimyte, E.M.; Smith, S.E.; Oreste, P.; Lembo, D.; Dutch, R.E. Inhibition of Human Metapneumovirus Binding to Heparan Sulfate Blocks Infection in Human Lung Cells and Airway Tissues. J. Virol. 2016, 90, 9237-9250. [CrossRef] [PubMed]

124. Kimberlin, R.H.; Walker, C.A. Suppression of scrapie infection in mice by heteropolyanion 23, dextran sulfate, and some other polyanions. Antimicrob. Agents Chemother. 1986, 30, 409-413. [CrossRef]

(C) 2020 by the author. Licensee MDPI, Basel, Switzerland. This article is an open access article distributed under the terms and conditions of the Creative Commons Attribution (CC BY) license (http://creativecommons.org/licenses/by/4.0/). 